Florida International University

FIU Digital Commons

FIU Electronic Theses and Dissertations

University Graduate School

$11-14-2014$

\title{
The Efficacy of San Lazaro and His Manifestations: Divine Mediators of Health Within Miami's Cuban-American Santeria Community.
}

Marisol Cribeiro

Florida International University, Mcrib001@fiu.edu

DOI: $10.25148 /$ etd.FI14110739

Follow this and additional works at: https://digitalcommons.fiu.edu/etd

Part of the Other Languages, Societies, and Cultures Commons, and the Other Religion Commons

\section{Recommended Citation}

Cribeiro, Marisol, "The Efficacy of San Lazaro and His Manifestations: Divine Mediators of Health Within Miami's Cuban-American Santeria Community." (2014). FIU Electronic Theses and Dissertations. 1641.

https://digitalcommons.fiu.edu/etd/1641

This work is brought to you for free and open access by the University Graduate School at FIU Digital Commons. It has been accepted for inclusion in FIU Electronic Theses and Dissertations by an authorized administrator of FIU Digital Commons. For more information, please contact dcc@fiu.edu. 


\title{
FLORIDA INTERNATIONAL UNIVERSITY
}

\author{
Miami, Florida
}

\section{THE EFFICACY OF SAN LÁZARO AND HIS MANIFESTATIONS: DIVINE MEDIATORS OF HEALTH WITHIN MIAMI'S CUBAN-AMERICAN SANTERIA COMMUNITY.}

A thesis submitted in partial fulfillment of the

requirements for the degree of

\section{MASTER OF ARTS}

in

RELIGIOUS STUDIES

by

Marisol Cribeiro 
To: Interim Dean Michael R. Heithaus

College of Arts and Sciences

This thesis, written by Marisol Cribeiro, and entitled The Efficacy of San Lázaro and His Manifestations: Divine Mediators of Health within Miami’s Cuban-American Santeria Community, having been approved in respect to style and intellectual content is referred to you for judgment.

We have read this thesis and recommend that it be approved

$\begin{array}{r}\text { Iqbal Akhtar } \\ \hline \text { Whitney Bauman } \\ \hline \text { Albert Wuaku, Major Professor }\end{array}$

Date of Defense: November 14, 2014

The thesis of Marisol Cribeiro is approved.

Interim Dean Michael R. Heithaus

College of Arts and Sciences

Dean Lakshmi N. Reddi

University Graduate School

Florida International University, 2014 
(C) Copyright 2014 by Marisol Cribeiro

All right reserved 


\section{DEDICATIONS}

I dedicate this thesis to my parents and my family, my husband and his family, my religious community and the Orisha. Without their influence, support and love, the completion of this work would not have been possible. 


\section{ACKNOWLEDGMENTS}

I wish to thank the members of my committee for their support, patience, and good humor. Their gentle but firm direction has been most appreciated. Dr. Stier’s guidance throughout my education has been invaluable. Dr. Whitney Bauman was particularly helpful in giving me positive reinforcement at a crucial time. Dr. Iqbal Akhtar's interest in an unfamiliar topic motivated me to narrate my research to an eclectic audience. Finally, I would like to thank my major professor, Dr. Albert Wuaku for having confidence in my abilities to not only complete my degree, but to complete a mile stone in life. I have found my time at FIU to be stimulating and thought provoking, providing me with a platform to explore both past and present ideas and issues relative to comparative religions. 


\section{ABSTRACT OF THE THESIS}

THE EFFICACY OF SAN LÁZARO AND HIS MANIFESTATIONS: DIVINE MEDIATORS OF HEALTH WITHIN MIAMI’S CUBAN AMERICAN SANTERIA COMMUNITY.

by

\section{Marisol Cribeiro}

Florida International University, 2014

Professor Albert Wuaku, Major Professor

This study explored the origins, evolution and influence of the tradition of San Lázaro as it currently pertains to the Cuban-American Santeria community in Miami. The main argument of the study is that in the context of the contemporary religious culture of Santeria in Miami, San Lázaro is a hybrid spirit. Though practitioners identify with specific manifestations of this spirit, the processes of transmigration have blurred the lines of deep-rooted faiths and created a fusion of meanings from disparate traditions, making San Lázaro an ambivalent personality. As

a deity whose personalities demonstrates the combination of a diversity of qualities, including those that contradict each other, San Lázaro is deployed in a very broad range of healing context, making him a versatile Orisha. This study clarified the contrasting qualities this deity embodies and traces the socio-historical context in which the deity acquires the layers of meanings it is currently associated with. 


\section{TABLE OF CONTENTS}

CHAPTER

PAGE

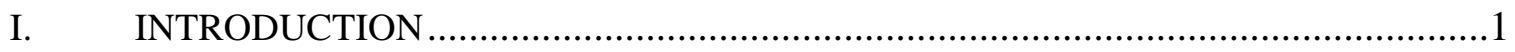

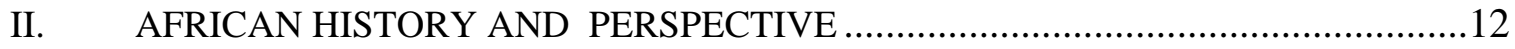

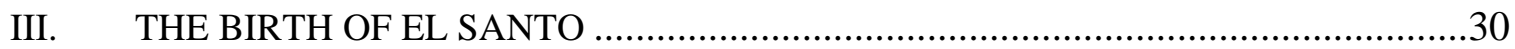

IV. CUBA TO MIAMI: THE PURPLE PASSAGE ....................................................44

V. CATHOLIC EXPRESSIONS AND THE EXPERIENCE OF CHURCH.....................55

VI. REFLECTIONS AND CONCLUSIONS ........................................................69

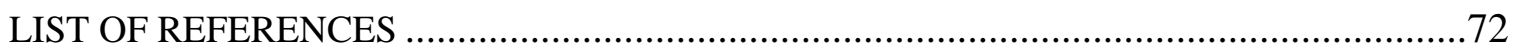

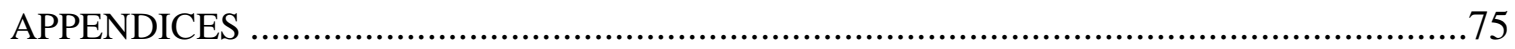




\section{CHAPTER I INTRODUCTION}

Within the Cuban-American community in Miami, the reputation of San Lázaro as a healing deity is undeniable. Catholic worshippers within the community praise him as Lazarus, Bishop of Bethany, and revered friend of Christ. In the Gospel of John [John 11: 1-46] NIV, he is portrayed as the brother of Mary of Bethany and Martha. The narrative here depicts Lazarus as the devoted friend of Jesus who becomes very ill eventually dies and is later resurrected by Jesus. Christian art depicts this Lazarus, wearing a purple robe and having a golden halo over his head, symbolizing his ascension into Sainthood. In other Catholic groups within the Cuban community of Miami, Lazarus is revered as San Lázaro or Old Man Lázaro [El Viejo Lázaro], who walks on crutches and is accompanied by a pair of dogs. In the book of Luke [Luke 16:19-31] NIV, he is described as a poor, sickly man, who waits for assistance from a rich man to offer him charity but dies waiting. Depicted as an un-well man covered in sores, surrounded by stray dogs, this portrait of Lazarus is known to represent the suffering of the ill and the sorrow of the world as a whole. Though these two biblical stories about Lazarus have nothing in common, many Cuban-American Catholics have combined them.

To make matters additionally complex, in Miami’s Cuban-American community of Santeria worshippers, which includes those practitioners who emphasize the Lukumi, Espiritismo and Ifa traditions, worshippers of San Lázaro give praise to two other very distinct representations. Both representations are similarly linked to the conditions and the misery of the poor. One of these Orisha is Babaluaiye [Father; Lord of the Earth]. "As a general archetype, the Afro- Cuban Babaluaiye is the divine being responsible for those who experience other forms of hardship. He represents those with skin disorders, bodily harm, immune syndromes, injured internal organs and in general all the miseries of the world. Secondly in the Ifa order [Lukumi clergy], there is a belief that "Asojuano", a manifestation or expression of Babaluaiye is similarly 
linked to human epidemics, such as small pox, yellow fever and even AIDS” (Wedel, 2004). All four of the above manifestations of this deity are understood in one way or another as mediators of divine health or miraculous healing within the Afro-Cuban migrant community in Miami. These four spirits, representing manifestations of San Lázaro, all have different origins, narratives and attributes. They also attract different worshipping styles. However, they are all venerated simultaneously on December $17^{\text {th }}$ in Miami for the same end results: health and well- being, in the context of a feast in honor of St Lazarus.

The main questions the present study seeks to address are how this deity came to accumulate these many layers of meanings, and why and how the Cuban-American community in Miami enlists the help of the different expressions in speaking to their day-to-day mundane and spiritual needs. Do the realities of its displacement, disease and quest for a renewed faith, lend this community the use of this spirit for guidance, or have mortality and morbidity enhanced the relevance of San Lázaro and his manifestations in Miami?

I argue in the study that in the context of the contemporary religious culture of Santeria in Miami, San Lázaro is a hybrid spirit. I use the term hybrid to refer to the integration of the many manifestations of healing entities that have come to merge in the representation of this spirit. Though practitioners identify with specific manifestations of this spirit, as the chapters of this study will show, transmigration has blurred the lines of deep rooted faiths and created a divine fusion. The chapters of the thesis are woven around the argument that San Lázaro’s ambivalence is the very quality that makes him such an important Orisha. As a deity whose personalities demonstrate the combination of diversity of qualities; including those that contradict each other, relevant to the maintaining of health and well-being, San Lázaro is deployed in a very broad range of healing contexts. This makes him a very versatile Orisha. I also argue that the sometimes contrasting qualities that combine in the person of San Lázaro are not a handicap to those who 
worship him. In the context of rituals relating to him, worshippers from different Afro-Cuban traditions simultaneously extend devotion to his different expressions, without any sense of confusion. On December 17th (The commemoration day) the synthesis and simultaneous worship of San Lázaro was evident throughout the city of Miami. I will provide an in-depth analysis of the fusion of spiritual forms that is San Lázaro: Miraculous Healer, Father of Pestilence and King of the Earth. I link this amalgamation to the flexible or fluid Afro-Cuban religious habitus which makes it possible for devotees to combine contradicting symbols all at once in the context of worship.

In my thesis, I intend to clarify the significance of the different expressions of San Lázaro that facilitate the well-being of members of the Cuban-American Santeria community in Miami. I explore the passage of the main or original manifestation, the Orisha Babaluaiye from his origins in Benin [West Africa] through the Cuban Catholic synchronism and to his present manifestation in Miami. I locate the discussion in the different eras of the history of Afro-Cuban worshippers of San Lázaro, identifying the forces that shaped the different constructions of the Orisha. To identify the motivation behind these different constructs, the study will emphasize the historic processes of transculturation in Cuba and how it has conditioned the worship of San Lázaro as a hybrid form. Like Johan Wedel, writer of “Santeria Healing”, who describes the importance of Orisha worship in Afro-Cuban healing practices, I will be considering the development of this particular Orisha and his authority in the community as an instrument of ethical teachings as well as the production of holistic health.

It is pivotal for the reader to take into serious consideration the fact that much of the information on this deity historically derives from the various oral traditions of the Yoruba and Fon people of West Africa. Hence, there is no such thing as a singular truth concerning the deities history, attributes, exploits etc. The discussions presented in this thesis are multiple viewpoints 
and legends and there is nothing absolute about the conclusions. So while the deity has different names among Afro-Cuban worshipper, my study, will refer to the deity as San Lázaro because this is how both the Catholic and the Santeria worshipper refer to the deity presently in Miami.

\section{LITERATURE REVIEW}

Currently, there are a few prominent writers of Santeria or Orisha worship especially in the USA, whose books make the book store shelves or the academic roster. Authors like Canizares, De La Torre, Ramos and Wippler are leading the pack, in what one Santeria elder called, “Commercialized Santeria”. These authors give the American English speaking audience an opportunity to educate themselves in the mysteries of Orisha Worship, without overpassing the ethical lines that the initiates hold in high regard. In the case of San Lázaro, the numbers of writers are reduced to an even smaller number. In the Afro-Cuban worshipping community the attitude towards San Lázaro, as I will explain later in the study, is characterized by fear, respect and secrecy. The sharing of information on the mysterious Orisha openly by the community is a recent development. This distribution of data would seem to be a response of the community to the growing interest of scholar in its religious expressions.

In his book, Santeria Healing, A Journey into Afro-Cuban World of Divinities, Spirits and Sorcery, Wedel informs readers about Santeria and San Lázaro quite comprehensively. He writes about the tradition of San Lázaro and Babaluaiye as a prime example of the healing experiences of initiates, but also gives examples of other Orishas and their divine intervention in the lives of those he studied. Wedel, a Swedish instructor of social anthropology, drew largely on numerous studies that he conducted in Cuba. Wedel’s position on Santeria and San Lázaro, is that it offers support and treatment for difficulties within the community. In his book, we find testimonies on sorcery, illness and healing and how the afflicted use San Lázaro to remedy their needs. 
Baba Raul Canizares [1955-2002], unlike Wedel, was an Oba [Santeria High Priest] in the religion and he shares profound religious practice with his reader. He introduces sacred stories, attributes, and spells associated with the African manifestations: Babaluaiye and Asojuano. In his book, Babalu'Aye, Santeria and The Lord of Pestilence, Baba Canizares seems to be writing for the initiate more than for the aleyos [non-initiates]. We find his direction to the initiates of the Santeria community, via language and his account of ceremonial instructions which only initiates could understand. For instance, in his book, Canizares describes the instructions for a variety of cleansings and spells that require the application of the initiate's elekes or collares [consecrated beaded necklaces] guerreros [Spanish word for warriors, or the Orisha Ellegua, Oggun, Ochosi and Osun] or Angel de La Guarda [Spanish word for Guardian Angel] He refers to the Orisha into whose mysteries the initiate has been ordained, which conveys the idea of partial or full initiation.

Michael Atwood Mason, born 1966 is also an initiated priest of the religion and is the director of the Smithsonian Center for Folk Life and Cultural Heritage in Washington, DC. As a researcher, Mason is known for his expertise in the religions and cultures of the African Diaspora. His book, Living Santeria: Rituals and Experiences in an Afro-Cuban Religion was nominated for an award in Ethnographic writing in 2002. Mason is currently publishing a cultural blog, dedicated to Babaluaiye by the name Baba Who? Babalu! In his blog, Mason shares his personal experiences as a priest of the Santeria religion as well as innumerable information about San Lázaro within a historic and religious context. In his blog, readers can find and share information about San Lázaro’s genealogy, African history, legends and the current view of the Saint held in the eyes of the Santeria community.

Much like the above writers, I found that there is an air of mystery when writing about San Lázaro. Whether it is purely superstitious or it has the potential to alarm Santeria 
practitioners, not many writers plunge deeply into research on San Lázaro. Those who do, all agree that this mysterious Orisha must be respected and not slandered. By producing an ethnohistory about the Saint, as well as detailing the manner in which the community communicates with San Lázaro by way of divination, I find that I can offer a distinguishing outlook to what San Lázaro can represent for the future of religious ethnography and holistic health care.

Currently, the model of health care in the West is at a crossroad. With health care causing concern in government as well as in the media, health care providers along with the ill are turning to new ways of healing. Western medicine has failed, by concerning itself primarily with physical homeostasis. Because "Western Medicine" is a science and beliefs often do not matter to them. Hence, it has rarely taken into consideration the underlying spiritual beliefs or traditions of the afflicted. In my study, I plan to shed light on how Santeria practitioners view homeostasis as well as the role that San Lázaro and his manifestations play in the community’s definition of health and healing.

\section{METHODOLOGY}

The acts people engage in for the purpose of social preservation are some of the most important factors that scholars must consider when studying a particular group. For over a hundred and fifty years, Afro-Caribbean cultures have puzzled the minds of religious scholars and social scientists alike. To date, one of the most controversial religious practices that has piqued the interest of scholars is Santeria. Its core practice, the sacrifice of animals, has especially given cause to researchers, viewing things from a "rational Western perspective”, to cast the practitioners as irrational, and their actions as cruel, savage and even primitive. Santeria has indeed been demonized as a result of such misunderstandings. Yet, the insiders, who partake in its ceremonies attest to Santeria's mysterious restorative properties, which they say are the byproduct of sacred transmissions between humans and the Orisha [African Gods]. These sacred 
transmissions is achieved by divination, initiation, ritual or embodied trance possession. These communications are indispensable elements of Santeria and its African predecessors.

For some time, the academy has studied the Afro-Centric faiths as products of oppressed and unintelligible people. These accounts have generated a historical misinterpretation of these peoples and their once reigning kingdoms and religious cultures. I make these remarks in view of the fact that it is vital for the reader to recall; that the origins of these African tribes and kingdoms had structures, their own modes of cultural production and held great knowledge in trade and medicine. Hence, I wish not to illustrate the culture behind the partition of oppressive fear and shackle captivity but to elaborate on San Lázaro and the Orisha within their historic royal linage. As De La Torre has noted, "These Africans were not the ignorant savages usually depicted; rather, they were members of a society which established property, holdings, conducted longdistance trade, and established different associations of commerce with business dealing deep within the African continent” (De La Torre, 2004).

As a religious studies graduate student at Florida International University as well as an initiated priestess and a practicing Santera [Santeria practitioner], living in Miami, I found that I had insight into the practice on both a subjective and an objective level. Because of the handicaps that accompany involvement in the Santeria culture, as well as Santeria's secretive stance on the ceremonial aspects of the faith, as well as the limitations it imposes on some categories such as females in matters relating to the Ifa order, it was important to me to offer the reader a window into how the community functions, as well as how some of the Orisha, specifically Babaluaiye, are used and understood. As a result of my initiation into the religion and the fact that I am an Apeterbi Ayafa; [ Spouse of a "Babalawo"[High priest of the Ifa order]/and guardian of the secrets of Ifa ], it was easy for me to engage in conversations with elders and other priest and 
priestesses alike, as well as aleyos [non-initiates]. My role in the practice helped me in the gathering of evidence on this divinity.

From the initial stages of this research, I decided to do an ethnographic study. Thus, my methodology involved the use of interviews and participant observation. I found that to retrieve the most current and accurate information about the Santeria community in Miami, I would have to immerse myself into most of the ceremonies and related events taking place in the Santeria worshipping communities in Miami.

This incorporation would be something that a non-initiate would probably not be capable of doing easily. Even if he or she was allowed to participate in ceremonies, there is still a possibility that he or she would misinterpret some observations. In my investigation, I studied the devotees of San Lázaro in their natural settings. The categories studied consisted of Cuban santeros, espiritistas, Ifa clergy, aleyos as well as Catholics who live in Miami. The age range of the persons studied varied from eighteen to approximately eighty years of age. However, the main focus group was females and males well above their fifties. Some of those interviewed had been educated in Cuba, before migrating to the U.S. For this reason they spoke little to no English. The research included interviews of members of the Santeria community and took place in the lower and middle class portions of Hialeah, Little Habana, Goulds, and Homestead. There are cities in Miami.

I selected those who wanted to speak to me about the subject under scrutiny and was able to gather evidence that offers the reader an understanding of why the community feels so attached to San Lázaro and his manifestations. During the course of the study, I engaged both with Lukumi practitioners as well as Catholic followers of San Lázaro, to ascertain the differences and similarities in their practices and views on connections to San Lázaro. For approximately six months, I journeyed through the neighboring Iles [Santeria homes of worship] that would host 
commemorative rituals to seek any data that I could overtly or covertly extract from the elders. During the study, I encountered a few elders of the community, who were not able to read or write in English or Spanish. Much to my surprise however, they were renowned experts in the practice of Orisha worship. It was a rarity to interview or engage in this subject with an English speaking individual. So I was grateful when I did find one.

During the research, I befriended the leader of the first Lukumi Church in the US [Church of Baba Lu Aye]. I interviewed Oba Ernesto Pichardo numerous times on his familiarity with the Orisha Baba-Lu-Aye and its history. My fieldwork also led me to Father Orlando Molina of El Rincon de San Lázaro in East Hialeah; a Catholic Church recognized and criticized for catering to the Santeria populace. Father Molina kindly enabled my research by allowing me to investigate the events at the church during the San Lázaro procession on December $17^{\text {th }}, 2013$. Father Molina also agreed to an interview that provides a Catholic perspective on this Saint gone astray.

I will also make evident through the use of my ethnographic investigations, how the community's habitus generates socially acceptable behavior for this group, as well as vindicate African wisdom as a durable and ever evolving currency. The text will also validate the application of this culture’s wisdom in the future. By using San Lázaro and his archetypes as prime examples of the significance of habitus amongst the Santeria practitioners in Miami, my work will provide a window into practices within the Santeria community, which one day can facilitate Miami at large.

\section{THEORETICAL PERSPECTIVE}

My demonstration of how the Afro-Cuban community’s ties to its African roots, have shaped the attitudes of generations of believers to San Lázaro and his archetypes, as socially acceptable deities of health, leads directly to Bourdieu's concept of Habitus. Bourdieu notes how, "Habitus is essentially the way that a culture of a particular social groups is embodied or 
internalized, in the individual, during the socialization process beginning in early childhood" [Bourdieu, 1977]. Expressed differently, Habitus is society written into the body, into the biological individual. Habitus is "a socially constructed system of cognitive and motivating structures” [Bourdieu, 1977]. Habitus is that invisible force behind the actions, feelings and thoughts of persons. The study engages the perspective of habitus to argue that the Afro-Cuban community of Santeria worshippers can be likened to the heritage of extensive religio-culture wisdom and knowhow stretching across generations and geographical regions.

Applying the idea of Habitus I use the idea of "Religious Habitus" is to denote the complex of emotions, thoughts and actions worshippers of Santeria embody by virtue of their participation in this religious culture. I argue that this religious Habitus transcends the social displacement of the community. The relevance of Babaluaiye then is linked with the received cultural and religious notions of illness, body, causation, spirit and gods in the Afro-Cuban community. The chapters that follow will reveal how the Cuban migrant's participation in the rituals associated with San Lázaro to overcome an array of difficulties in Miami, is in keeping with their cultural heritage. The research also provides a historical outlook on the Obaluaiye tribe, which is said to be a direct predecessor of the concept of Babaluaiye and therefore San Lázaro. The contemporary tradition of the Lázaranian worship illustrates how this healing deity has transcended time and space and has blurred religious lines to become embedded in the very fiber of the Santeria community in Miami.

In Miami, Catholics and Santeros alike are receiving much needed support from the saint. Biblically, San Lazaro is a teacher of morals. San Lazaro teaches about the treatment of the sick, poor or less fortunate. San Lazaro is also a symbolic expression of rebirth. In Santeria San Lazaro is an ethical teacher and divine example of action and consequence. These two distinct expressions have become distorted. Today’s Lázaranian worship and the behaviors of his 
devotees partake in will allow the reader to appreciate the influence San Lazaro has within the Santeria community. From childhood, Santeria practitioners, whether Cuban or American have internalized the concept of the Orisha and their restorative powers. The notion of San Lázaro and his efficiency as a miraculous worker is part of the embodied Africanisms of the Santeria community. It is through habitus, that many African behaviors and customs have remained steady throughout history.

In the context of the Santeria community, we find that Cultural capital can illustrated by the utilization of medical divination practices by its devotees; as well as practitioners' ability to harness divine energy by way of trance. Other significant cultural capital held by these people, is their familiarity of pharmacopeia, their ritual cleansings, and there absolute alliance with San Lázaro. These types of customs and activities are second nature to the Santeria community, as it is part of their everyday lives. It is through these sacred implementations within the community that this African culture has found a way to survive civil unrest, war, slavery, sickness and migration. For Santeria practitioners, it is these rituals and these ancient divinities that can help explain and influence life and all its mishaps. It is through these forms of rituals that, that African knowledge can be categorized as durable and transposable, giving today’s Santeria community boundless capital. Assuming that habitus is an internalized and innate awareness, I will be revealing how after four hundred plus years of changes to their system, African methods are still used to generate support for their community and can be classified as ever evolving .

Currently, Santeria practitioners do not have the same needs as they did in Africa or Cuba. No longer is this community struggling against the oppressive nature of the Oyo kingdom or restraints of Castro's communism. Nowadays, Santeria practitioners in the United States are facing new challenges; they are restricted by new limitations in their social conditioning such as language, fear of government and lack of financial stability. One factor that I found to be 
essential was that the majority of the Santeria community in Miami is Spanish speaking, which makes it hard for them to feel comfortable within a system. Fear of the United States government because of the limitations of their past and lack of trust towards the system plays a vital role on this community's application of Santeria for a variety of issues. Lastly, the community’s familiarity with San Lázaro and his manifestations provides a support system for the CubanAmerican Santeria community in Miami that spans four hundred plus years, two Diasporas and a number of other trials. That is why Cuban migrants, with secular resources, such as medicine and technology still look to San Lázaro and his manifestations as pillars of hope.

African habitus at its core is one of augmentation and omission, therefore it manifest itself in times of need. "Habitus is also a principle of both social continuity and discontinuity: continuity because it stores social forces into the individual organism and transports them across time and space; discontinuity because it can be modified through the acquisition of new dispositions and because it can trigger innovation whenever it encounters a social setting discrepant with the setting which it issues” (Bourdieu, 1990). My research will show how today's Lázaranian worship has traces of both continuity and discontinuity within the ritualistic sphere of it cultural production. It will also elaborate on modifications within the system that will allow non-Santeria practitioner to benefit from it shifts.

\section{CHAPTER II AFRICAN HISTORY AND PERSPECTIVE}

To consider the role of San Lázaro as interpreted presently by the Santeria worshipping community in Miami, I will explore the origins of one his primary manifestation, Babaluaiye. I will also shed light on customary African principles that will help the reader understand the deity’s contemporary forms. The Yoruba, [The Yoruba is a reference to the group of neighboring villages in Southwest Nigeria over which the people of Oyo imposed hegemony]. The Oyo 
functioned both as political and religious centerpiece, making the Yoruba a religious guided peoples. De La Torre describes the group in the following words:

The Yoruba settled along the northeastern shore of the continent of Africa in an area that today is southern Nigeria, probably migrating to this area from the east, from either Mecca during the rise of Islam, or the Upper Nile region during the ascent of Christianity. By 1000CE, small city-states began to develop along the coast between the rivers Mono and Niger. Three major Yoruba kingdoms developed in the region, Benin, Dahomey, and Oyo, each playing an important role in the affair of the others, and all three playing a major role in the slave trade to Cuba" (De La Torre, 2004).

These three kingdoms were said to be the collective family of the great Oduduwa [First god king] of Ile-Ife, "the city of human origin and the sacred center of the Yoruba world" (Olupona, 2011). Though these three kingdoms were a collective family, it was not unusual for them to have disputes and power struggles among their leaders. According to Murrell, "Since the late 1700s, internal disputes over power related trading, the size of the kingdom, slavery, attacks from the Muslims, economic decline, leadership weakness, civil wars and secession by the Egbas and Dahomey led to the Oyo empire; it was invaded by the Fon-Dahomey people, whose slaveraiding campaigns became a significant supply line for the Atlantic slave trade” (Murrell, 2010).

Historically, the Yoruba people have developed and assigned identities to hundreds of deities to suit their most urgent necessities. For instance, women having difficulties conceiving, would ask for the assistance of Yemaya [Orisha of the Ocean/Mother of all creatures of the Earth] to bless them and allow them to carry a seed. On the other hand, in times of distress such as civil unrest or war, it was the force of Oggun [Warrior Orisha] which would be addressed. Likewise, all matters of the human existence had an Orisha which pertained to a specific demand.

Babaluaiye was the Orisha petitioned in times of suffering.

The Orisha can be understood as a collection of divine entities that are on the Earth to do God's bidding. They are said to be all that is in nature as well as all that surround's human on their terrestrial journeys in life. The Orisha are divine energy; both explained and unexplained. 
The tradition of Orisha worship can be identified as a modified form of monotheism, and the Orisha are dependent on the ultimate power and authority of Oludomare [Supreme God]. Similar to the great Gods of the Greeks and Romans, the Orisha provide meaning to the daily issues that puzzle the members of the Yoruba communities. De La Torres notes of the Orisha:

The early Yoruba developed myths about the Orisha in order to make sense of the dangers, uncertainties, and arbitrariness of the natural world that surrounded them. These myths, and the rituals that accompanied them, offered explanations for why the forces of nature operated the way they did. The Orisha became sources of strength and security, in control of forces over which human beings had no power. Raging seas, violent thunderstorms, harrowing winds, even death did not have to be feared when they were identified with the Orisha-the same Orisha who cared for and responded to the offerings of their devotees (De La Torre, 2004).

In the Yoruba cosmology there are more than 401 Orisha. However, a significantly lower number of Orisha are now being utilized by the community in Miami. Las 7 potencias Africanas [The 7 African potencies] are the most often utilized. They include Ellegua [Orisha of the crossroad], Obatala [Orisha of creation], Chango [Orisha of fire] Yemaya [Orisha of the oceans] Oshun [Orisha of the rivers] Oggun [Orisha of war and metals] and Orunmila [Orisha of divination]. Along with those seven prime Orisha; Ochosi [Orisha of hunting], Babaluaiye [Orisha of health] and Oya [Orisha of the winds] are also an essential part of the Yoruba world view of those that practice Santeria in Miami.

The Yoruba societies that live on today were constructed by this pantheon and other numerous associations between man and God thousands of years ago. Though Orisha worship was not a religion at the time of its origin in Africa; the 1974 Supreme Court case between the Church of Baba-Lu-Aye and the city of Hialeah that Orisha Worship/ Santeria ended with it acquiring the status of a credible religion in the U.S. The Orisha are recognized as the celestial agents of Oludomare who assist the human agent through acts of devotion. The African Orisha have personified characteristic, faults, favors and divine powers. The Orisha tradition differs 
from models often cast as polytheism because the Orisha are said to be the keepers of the celestial Ashe' [energy] which is the energy of God. They are therefore dependent of Oludomare.

Ashe' is the indispensable essence of Oludomare and everything in nature. De La Torre notes how" "In Santeria, Ashe’ is a sort of primal energy that comprises the power, grace, blood, and life force of all reality. It is amoral, neither good nor bad, unable to be seen or personified, a neutral cosmic energy undergirding every aspect of existence” (De La Torre, 2004). Much like Chi or Prana, in Oriental traditions, Ashe' is perceived as a life force that subsists within us and amongst us. Body traditions, such as Tai Chi and Yoga center their ideologies in sustaining the balance of such force. Ashé is what some scholars would call a non-anthropomorphic form of theism. The Yoruba believe that individuals who master the obscurities of Ashe' are able to apply them for the betterment or demise of individuals or groups as it is directly connected with God.

The Yoruba culture stresses reliance on Ashe' for its command in the Universe. Along with the acceptance of Ashe', the Yoruba are also confident in the interaction of past ancestors as a driving force within their everyday activities. Therefore the Yoruba follow both the rules of animism and spiritism. For the Yoruba people, ancestral worship and the idea of anima [soul] are essential keys to their way of life. To comprehend the beliefs which revolve around these peoples, I offer the following explanation from Erickson who shares that,

The foundation of spiritism includes the following beliefs; 1 .There is a spirit energy or vital force in the world and this vital force is part of all natural and supernatural phenomena. 2. Humans have both a physical and a spiritual body. 3. There is a high God who is the source of the vital force and all life and nature. 4. This high God communicates with the world through spirits that include guardian spirits, ancestors, and natural spirits. 5. Spirits constantly contact the physical world. 6. Humans can be contacted by and can learn to contact, channel and embody or incorporate the spirits [primarily through possession] for healing and spiritual evolution. 7. The role of humans is to keep the vital force that sustains and animates the world moving by praising and nurturing the spirits (Erickson, 2008). 
The way that the Yoruba praised and nurtured their Orisha was through feats of devotion such as singing, dancing, offerings and blood sacrifice. Another way the Yoruba have also kept the Orisha tradition alive throughout history is by the use of Patakis [myths] and Odus [prophecies associated with the sixteen spiritual forces of Ife-Ile \{city of origin of the Orisha\}]. The Patakis and Odus assemble the cardinal concepts and moral underlining for the group. It was through these myths that the group would shape their norms. Taboos, gender roles, mating rituals and a vast array of social standards would be constructed through the stories of the Orisha. According to anthropologist Clifford Geertz, "legends or myths can provide both a model of reality and a model for reality. While they inform of the day to day dynamics of life, they are also capable of shaping those dynamics” (Geertz, 1973). It is through these Odus and Patakis that the Yoruba shape their lives. The Yoruba took from these stories the definitions of love and war, faith and wisdom, health and death and inserted it to the moral agenda of all human existence.

Unlike monotheism, the Yoruba's creation myth gives the Orisha a centralized role in the lives of humans. The genesis story of the Yoruba begins with an ultimate creator Oludomare, who is both the Mother -Father God of all things living and non-living. She/he is known to maintain distance from humans because of its awesome power and therefore is not involved with human affairs. In portions of the Cuban tradition, the awesome power of Oludomare is expressed as a trinity. Oludomare [represents the omnipresent who does not make contact with humanity] Olorun [represents the God of the Sun] and Olofin [represents the God that walks with man]. In the hierarchical system of the Yoruba, Oludomare is recognized as the owner of the skies, and is at the top of all creation. He/she is followed by all the Orishas, or lower deities, next by Eggun, or ancestral spirits. The next in line are humans, who are then followed by plants and animals, and lastly are all non-living things. Though that hierarchy does not place humans on the top of the food chain, it does give followers a chance to gather much needed support through the agent of God's will. 
The devotees of these religious traditions believe that the moment humans are born, they are blessed and have a world of divine opportunity ahead of them. In the Odus of Ifa [sacred text of the Ifa clergy], “Ojuani Shogbe”, the primary aphorism is "Everyone is born with a blessing”. Whether in the tribes of Africa or in today's Iles [Santeria houses of worship] it is the opinion of the community, that humans are born to be blessed but through daily trails of life, we begin to alter our once blessed identity. These trial and the way in which people react to them create a lack of Ashe', generating inertia, discomfort or even death. For Orisha worshippers, all changes grand and trivial are believed to be associated with Ashe'.

\section{HEALTH AND ASHE'}

Orisha worshippers believe that Ashe' is not a stagnant creation, Ashe' is ever changing. It is believed that Ashe' is something that we are born with and as such it is something that can be altered both positively and negatively. Ashe' is the core of all things alive and as such can be improved or weakened by practices conducive to Santeria. If an individual has a plentitude of Ashe', the Orisha's blessings are said to reach the devotees, giving them the potency to live a healthy and harmonious life. Health and harmony subsequently become the natural derivatives of a good source of Ashe'. If a person's Ashe' is diminutive on the other hand, he or she is probably experiencing some difficulties. The ultimate goal of enthusiasts is to acquire as much additional Ashe' as they can so that they can attain their desires; usually health, love or prosperity. Issues such as discomfort, immorality, and malevolence can all be defined as a lack of Ashe'. Orisha worshippers believe that each person's Ashe' internally encourages the circumvention of imbalance. Since Ashe' is ever changing, followers believe that feats of sorcery can also affect ones Ashe”, and in part their well-being.

Illness and an early death are frequently pronounced in terms of sorcery and are most often related to envy or misconduct. When a person has done well for himself and built a stable home, he is at risk of the "evil eye" which is transferred onto a person through 
jealousy. In other words, someone who is very jealous of you could use the power of sorcery to send negative energies of spirits to invade your life, and in some cases, end it. Illness then, transpires in the social body and is likewise socially experienced (Wedel, 2004).

Generally when someone becomes sick or has difficulties that include but are not limited to issues of health, relationship or employment, it is said that that person was dealing with some kind of disease causation. For this community, disease is not measured solely by physical wellbeing but complete social homeostasis. Those who follow this tradition identify two kinds of causes, natural and supernatural. For these people, there is more to life than meets the eye. The sense is that humanity is not alone in this life is ever present, and the idea that one has to be aware of one's surroundings on a universal level versus simply terrestrial is evident. In this connection Murdock identifies two underlying theories of disease causation: natural and supernatural causation. He writes,

Theories of natural causation included infections [invasion by noxious organisms], stress [exposure to physical or psychic strain], organic deterioration [organ failure, hereditary defects], accidents [unintended physical injury] and overt human aggression [willful infliction of bodily injuries on another human being." "Theories of supernatural causation include three subcategories: mystical causation with four specific causes- fate[ascription to astronomical influences, individual predestination, or ill luck, ominous sensations[potent dreams, sounds, sights, etc.], contagion[contact with polluted object, substance or person], and mythical retribution[ violation of taboo or moral injunction]; animistic causation with two specific causes; soul loss; voluntary or involuntary departure of the soul from the body] and spirit 1,being]; and magical causation with two specific causes- sorcery [aggressive use of magical techniques by a human being either independently or with assistance from a shaman] and witchcraft[ voluntary or involuntary action of a person believed to have special powers and propensity of evil](Murdock 2008).

Largely those who abide by this order consider the idea that they could be receiving punishment from by the Orisha or Eggun. Retribution for a dishonest act or the actions of past generations can also haunt particular families or tribes for centuries. Others fear the evil eye or envy and link these to their physical afflictions. Several people believe that it is the work of the ancestors themselves that have cause dislocations in their lives. It is in the context of the fear of 
supernatural agents of harm and the banality of their malevolent effects on human communities that the Orisha Babaluaiye, who is the subject of this study has meaning. This is the Orisha who fights off disease and restores health. At their origin, all the Orisha had children or tribes that represented them and adopted them as patron deities. These associations distinguish one Orisha from the other. All the Orishas have control over specific spheres of life or experience, natural and human. The alleviation of disease belongs to Babaluaiye and his children or agents.

From the commencement of an individual's journey in Orisha worship, a few things are clear. Oludomare, Olorun and Olofin are given the highest of respect. Honorific titles reflecting different attributes of God among the Yoruba, these are currently personified and cast as the trinity in the Cuban portion of the Yoruba religious experience. The Orisha love and support their children within the realms of their terrestrial lives. Yet, while compassionate the Orisha are stern, and much like a parent if one gets out of line, the Orisha will punish the person. The Orisha, dissimilar from the many forgiving Gods of the world, do not allow for immorality without consequence. Babaluaiye arguably represents the epitome of this trait associated with the Orisha.

\section{BABALUAIYE}

The Yoruba traditions have recognized Orisha Babaluaiye [King of the Earth] as the Orisha of health and well-being for over four centuries. The Yoruba are confident that this Orisha is the owner of all the Earth and as such is a primary god within their pantheon. The fact that the Earth is the doorway to the resting place of the dead [underworld], gives the Yoruba the conviction that both life and death are within the scope of Babaluaiye's divine domain. The religious history of the Orisha shows how he is the product of a cross fertilization of religious ideas of the Yoruba and the neighbors from Dahomey. 
In Dahomey he is Sagbata / Sakpata, the eldest son born of Mawu and Lisa [God] and is the most prominent deity of the earth pantheon. His cult is maintained and celebrated by knowledgeable priests and adept in the intricacies of his rituals in Dahomean and select parts of Habana, Regla and also by the Arará cult of Matanzas Cuba. Sakpata is called Sònpònnó in Yoruba. Another popular praise name for him is Asojuano or Asowano, names are commonly used in Cuba by the Ifa clergy. These names comes from the Fon epithet Azohani, an ancient praise name for this deity among the Mahi of the North of Dahomey. This is arguably the origins of the usage Asojuano, the most common reference to the Orisha in Cuba. Murrell adds a new perspective to this history. He notes that,

Sakpata [Shopona, Shakpata], also called Omolu and associated with Babalu Aye, is the son of Iemanja and the god of diseases like AIDS, leprosy, smallpox, and other epidemics. He is also the deity of health and of the earth's environment and doubles as St. Vincent, St. Jerome, and St. George, or St. Raphael. His devotees must wear red when he is to manifest his presence. Because of his connection with sickness, evil and prophetic utterances, many followers fear him (Murrell, 2010).

In the Arará tradition, Asohano/ Asojuano expresses a need for honorific and flattering titles with which worshippers must praise and placate the Orisha. Although considered benevolent by many, Asojuano is known and revered as the deity of pestilence, virulent diseases, disfigurement and the social-cultural experiences of marginalization, displacement and discrimination. The sense is, that he knows these worlds first-hand, and so holds the power to miraculously heal the mind and body, to avenge wrongful behavior and to mete out both punishment and reward. Worshippers avoid calling on Asojuano by his most intimate and powerful names lest he or she be seen as presumptuous. This deity of extreme power is treated tenderly. Worshippers call and adulate him by his myriad of epithets which extoll his greatness and power. Asojuano is known as:

Obalùayé King of the world 


$\begin{array}{ll}\text { Ilègbónó } & \text { Hot earth } \\ \text { Olóde } & \text { Lord of the world } \\ \text { Oba } & \text { King } \\ \text { Olùayé } & \text { Lord of the world }\end{array}$

Asojuano uses a scepter or broom made of palm ribs that is loaded with medicines, wrapped and adorned in beads and consecrated to sweep sickness and dis-ease from the human body. Orisha priests that have undergone the ceremonies particular to this Orisha receive a ha, [a Fon word meaning "broom" but often written as "ja" by Spanish speakers], along with the other ritual emblems of the deity to be used for healing and keeping $I k u$ [death] in abeyance. Murell describes the Cuban portion of the Asojuano tradition:

Cuba's creole name for the Ewe-Fon- Dahomey Shopona, or Chankpana, god of illness, who can punish and kill through disease, cross-dresses as St. Lazarus. This deity reigns supreme in Santeria houses and requires submission to his authority. As a sign of his most characteristic work and association, he dresses in jute and sackcloth to replicate the ancient biblical symbol of distress and pain. He also has a bag strung across his chest in which he carries his favorite food, corn, and has a dog (or dogs) who frequently cleans his wounds (Murrell, 2010).

As mentioned before, it is through the use of Patakis and Odus that we can obtain characterizations of this spirit. Building on these oral genres, the Santeria community agrees that Babaluaiye initially arose from the Dahomean cult of Oba-lu-aiye in Africa. There are few legends that speak about Babaluaiye’s genealogy. However, they are inconsistent. Some say that he is the son of Yemaya [Orisha of the Ocean]. Others claim that he is the brother of Chango [Orisha of fire]. Others state that Babaluaiye come from a direct lineage of Nana Buruku [Orisha of the underground waterway] and is her son, while others make assumptions that he is her spouse or lover. In Candomble' [Brazilian Afro-Religion] there is a correlating legend that reconciles the conflicting stories above making better sense of about Babaluaiye's, early years. 
According to this myth, Nana-Buruku was Babaluaiye's' true mother. Nana Buruku is a Fon deity associated with the creation of the universe. In the Yoruba tradition she is a mysterious Orisha known for her beauty and her association with underground waterways. Nana Buruku is a feared Orisha because death always accompanies her, and she is associated with infectious diseases. The tradition has it that Nana-Buruku left the newly born Babaluaiye to die from exposure at the edge of the ocean's shore. Severely scarred and weakened, Yemaya found the child, trembling, feverish and frail and nurtured him back to health. While in the care of Yemaya not only did Babaluaiye become healed but he learned the many mysteries of Yemaya's healing attributes. Thus having been associated with goddesses that represents dread and death on the one hand, and life, health and healing on the other hand, this Orisha combines the propensities that make him both the healer to the sick as well as the wrath of the supreme God against those who have corrupt or malicious actions towards themselves or humanity.

For the Yoruba even mentioning his name is something of a risk. It can bring sickness and even death. In the Orisha tradition of Yoruba, he is closely related to leprosy, smallpox and all skin disorders or disfigurements. His attributes are numerous as he can be associated with a variety of human conditions. For instance, he is affiliated with the Earth and all that lies in it; including all the dead bodies. He is associated with displacement and exile as the text will describe. He is associated with obedience and lack thereof, disfigurement and all physical ails. He is king of the Earth, but also represents the collective suffering of humanity. This very complex spirit has an abundant and rich history. In African religions and its offshoots, these gods are often masters or supervisors over experiences they have participated in. In what follows, I describe some myths in which Babaluaiye himself participated in experiences that led him to the acquisition of traits assigned to him. 
One of the most recited Odus regarding Babaluaiye is in the Ifa's clergy's Odu OfunOkanaran. This story explains how Babaluaiye pays a steep price for his dis obedience. The idea of cause and effect, that is, engaging in acts and having to face the repercussions of life's choices are illustrated in the following tale. Babaluaiye was a young handsome prince who is described as rebellious and sexually driven. He and Chango are portrayed not only as great friends but also pseudo-equals in the art of female seduction. Blessed with charm and beauty they were both known for having their way with ladies. The traditions says, that one day Olofin tells the Orisha that during Semana Santa [Catholic Holy Week] they should practice abstinence as a mandate from the most-high, Oludomare. Unfortunately for Babaluaiye, Oshun [the Orisha known for worldly pleasures] was in his presence and with profound familiarity and disregard for the instructions given by the elder Olofin; Oshun and Babaluaiye were intimate; going against the orders of Olofin and subsequently Oludomare. The consequences of his disobedience are what is known as Babaluaiye's divine punishment in the tradition.

Babaluaiye's penalty for being disrespectful to his elders was severe. He contracted all the infectious diseases of Yoruba land; amongst them were smallpox, leprosy, boils and syphilis, just to name a few. Furthermore, none of the other Orisha helped him or offered any support because he challenged Oludomare. It was not long until Babaluaiye was covered in sores and other bodily signs of pestilence. The smell of death permeated his flesh and he was fragile with failing health. No one helped him or presented him with any offerings that would restore him. Even his own sons disrespected him, as they laughed because he had trouble seeing and walking and was forced to carry a cane [JA]. The only Orisha who looked on him with pity was Eshu [Orisha of the crossroads].

Babaluaiye, repudiated by his own people, exiled himself to a distant town. When he would pass a town or village the people would throw water across his path and say "Molo boro" 
[take harm with you]. Humble and in pain, he would walk and bless all those whose trail he passed. It is because of this legend that the use of water is limited in ceremonies that have to do with Babaluaiye, although water is an essential part of ceremonies linked with most of the Orisha. The elders of the tradition explained that when Babaluaiye was full of sores, the water which people would throw at him would sting, irritate and even burn his flesh. Hence, when dealing with this Orisha, the use of coconut water [agua de coco] and dry wine [vino seco] substitute for water.

In his travels, Babaluaiye met with Eshu who took him to Orunmila [Orisha of divinity], in the land of Ole Ile. Orunmila consulted Ifa and told Babaluaiye that he had been rejected because of the lack of discipline and disobedience. But he would be greatly admired and loved in another land. First however, he would have to make Ebbo [sacrifice or offering], which will alleviate some of his troubles. He should also find a dog to be his constant companion.

Babaluaiye followed the counsel of Orunmila by making ebbo and gave thanks to Eshu. When Babaluaiye left, Eshu presented him with a dog that some say that he got from Oggun. This dog or dogs became his companion due to Babaluaiye’s unbearable smell of decomposition. This myth about Babaluaiye gives insight on how the spirited allegiance with canines that this character came to be, in the Yoruba tradition.

Babaluaiye continued on his way until he reached Dahomey. The people of Dahomey paid homage to all the terrestrial Orisha [Orisha of the Earth/the soil]. At that time, in that land, everyone lived on their own except the king, who believed himself to be God. The king of the land, murdered, stole and did as he desired, without any compassion for the consequences; but at the sight of Babaluaiye, the king knelt at his feet and asked for forgiveness for his wrong deeds. Olofin thereafter blessed Babaluaiye for listening to Orunmila. Then Olofin anointed Babaluaiye with a fish and cleansed Babaluaiye of his maladies. This is how Babaluaiye established his kingdom and his traits amongst the Ewe Speakers [Fongbe, Arada, Arará] of west Yorubaland” (Mason 2013). 
In this myth, we find shame, isolation, migration and all the trials accompanied with these elements. We find the hope of being healed via good intentions as well as the idea of miracles being the product of divination, obedience, good deeds, and ebbo.

In another Yoruba myth Shopona is another manifestation of this spirit and is represented as a frail old man. The myth states that Shopona had difficulty walking and seeing and could not get around like he used to. One day Obatala [Head Orisha of the pantheon; creator of humanity] was having a gathering and he invited all of the Orisha. While they were assembled together, they began to dance and enjoy the festivities. It was at that moment that Shopona fell to his knees in pain. The Orisha acting like children laughed at his misfortune. In anger, Shopona intended to infect the Orisha with pox and deformity, but Obatala being an elder deity stopped him and drove him out of the area. Shopona became an outcast from then on. He was alone, left to wonder and rage set in, and his wrath was then directed at wrong doers and those who hurt others in unjust manners. "Although Obatala was able to contain the disease among the Orisha, he was unable to fully contain them among humans, and so disease entered the world” (De La Torre, 2004). This legend like many others gives us a sense of these spirit's rage and his capability to be an instrument of atonement of justice when need be.

These two stories give followers of this divinity, the idea of Babaluaiye in various characteristics: A rebellious youth, confronting the consequence of his action and being inflicted with punishment and isolation for his wrong doing, a miraculous healer, and a teacher of moral instructions toward human suffering and a symbolic figure of determent pertaining to injustice or unethical behavior. This gives Babaluaiye a compassionate yet stern stand point in his actions toward his petitioners. It is because of these themes, that Babaluaiye has generated countless associations with him and applies them when need be.

As symbols attain a cultural life beyond any particular work of the imagination, symbols can become archetypes. Archetypes according to Swiss psychiatrist Carl G. Jung, “are innate 
universal psychic dispositions that form the substrate from which the basic symbols or representations of unconscious experience emerge”. Jung noted how” The term 'archetype' can be misunderstood as mythological images or motifs. He notes that these are nothing more than conscious representations. Such variable representations cannot be inherited. The archetype represents a tendency to form such representations of a motif-representations that can vary a great deal in detail without losing their basic pattern" (Jung, 1968). Jung offers the "Wounded Healer” motif as an example of an archetype and as an explanation to the reasons why healers who required some kind of healing themselves sublimate their personal healing onto others. The idea of the wounded healer in culture comes back to one primary truth, the wounded healer's initial appearance is of an injured or a faulty character who through the grace of divine admission becomes healed and then heals. My sense in this study is that Babaluaiye is a reflection of this archetype in Santeria.

Babalu' is himself afflicted, usually with smallpox or leprosy, in the stories that have been spun about him. Yet in spite of his conditions, he always endures, limping along accompanied dogs, for no human companion will countenance one so hideously disfigured by illness-to become king and inherit the Earth. In this connection he provides a stirring role model for all who suffer and testifies that however horrible its circumstances, life is worth living (Canizares, 2000).

Followers of Santeria view him as a fundamental model of human existence and selfdiscovery. The representation of sickness and of death, demonstrates the mortality of every human, and his redemption, represents hope. Babaluaiye is a teacher or better yet a mentor for all of humankind. He clarifies our role within the physical as well as the spiritual world. It is through Babaluaiye that humans acquire the laws of cause and effect. He demonstrates that good behavior is praised, and negative behavior is punishable. He shows how people must abide by certain earthly and divine principles weather they choose to accept their authority or not. Babaluaiye is a teacher and as such he tests humans to see how they react during a moment of 
crises. He takes notes on human predicaments especially when a person's world gets out of balance, he watches and pays close attention to actions and reactions.

In the discourse of Santeria, for example, abundant financial capital during a lifetime is irrelevant when one reaches an age of physical deterioration. Once a person's days of end begin closing in, that is when one focuses his or her reflection on Babaluaiye [Father Time]. Babaluaiye works in close partnership with $I k u$, [Orisha of death], whose function is to take the human spirit from its terrestrial existence, when their time on this earth has expired.” Like a conductor, Iku takes a person to his or hers next destination, no matter the amount of riches left behind. For the community, it is through positive deeds and pure intent that one finds peace when departing this life. It is through the trial of life that Babaluaiye teaches the community how to measure spiritual will and physical mortality” (Mason, 2010).

The recurring dichotomy of this spirit can be traced back to the Dahomean cult of the Oba-Lu-Aiye. Prior to the Trans- Atlantic Slave Trade, the West African regions and its tribes were constantly involved in civil unrest. Political chaos and the need for human contraband generated multiple attacks on neighboring regions. De La Torres shares,

Their homeland suffered the ravages of political unrest, chiefly caused by the slave trade, as kingdoms rose against kingdoms for the purpose of acquiring humans to sell to the European slavers. Benin, Lagos, Bonny, and Calabar became chief centers of the slave trade. The formerly stable kingdom of Benin was badly shaken by the rise and subsequent decline of the Oyo kingdom; in addition, civil wars broke out as royal houses struggled within themselves for supremacy (De La Torre, 2004).

These war like conflicts, allowed for the tribe of Oba-Lu-Aiye of Benin to stand out from the rest. Known for their advancements in biological warfare as well as innovations and curative rituals this tribe was both respected and feared. A respect and fear that through the centuries has remained durable and transferrable. This tribe was renowned for their familiarity about the human body and curative advancements. They were also the first peoples to use what today we call biological warfare. In my interview with Lukumi expert Oba Ernesto Pichardo he stated, “The 
priests of the Oba-lu-Aiye tribe used inoculation on their own members after an outbreak of smallpox would occur and with such rituals they were vaccinating their members from the varieties of disease and infection”. Oba Pichardo also revealed to me some of the history of this tribe. He specified that,

The Oba-lu- Aiye cult was known to have great curative knowledge of the human body. During times of war this tribe was the first one to use germ warfare or biological warfare against neighboring enemies. The way that they would do this would be by using a spear like stick $[J A]$ and position it where decaying corpses were laid to rest. These corpses which usually died from smallpox or from other contagions where full of bacterium. They would then get the spears and poke the dead carcasses of these bodies. In the evening they would use a camouflage and go out to the neighboring enemy territory which was damp and muddy and they would stab the dirt. At that time the area would then be contaminated with smallpox or yellow fever or any other contagion" (Pichardo, 2014).

They were healers, and they were killers. They were the medicine men, the witch doctors; they were the unexplainable and authoritative force of life and death. “According to Melville Herskovits, the Sakpatases, [priest of Babaluaiye in Dahomey], always dress in a beautiful loincloth, that is richly ornamented with jewels and silver. Which seems to be an indication of the royal status of Babaluaiye/ Sakpata among the peoples of the former kingdom of Dahomey” (Herskovits, 1969). Sir James George Frazer explains this type of authority in the following statement,” It is not by accident, he observes, that in primitive cultures the person who can claim mastery of its techniques- whether called magicians, medicine mam, or witch doctor. Almost always holds a position of considerable prestige and power. Usually in fact, the magician rises to the role of king, since he best knows how to control the natural world for the good of the tribe or for the evil of its enemies” (Frazer, 1935).

The cult of Oba-Lu-Aiye had used these advances so they were feared for the catastrophic influence they had as well as respected for their restorative dominance. So persuasive and commanding was the tribe, that when the British invade Lagos in 1851, the Oyo Empire was 
dismantled and the Oba-Lu-Aiye tribe of Dahomey [Rep of Benin] was banned from practicing their rituals any longer.

Today this fright and respect are prominent factors when inquiring about this spirit. Throughout my research, I found numerous persons who wished not to speak of this spirit, even though they didn’t mind speaking about Santeria in general. It was as if anxiety dominates when discussing Babaluaiye. I found that this spirits healing energies sometimes take a back seat to his wrath in the eyes of the community. Even though I did have the chance to speak to some elders who gave me a greater understanding to the loving and humble aspects of Babaluaiye, distress was frequently present. It seems as no one wanted to receive Babaluaiye’s Osogbo [Negative Ashe’].

Unlike the Christian perspective of an afterlife, where heaven and hell are your only options to the afterlife; by way of judgment. Orisha worship brings heaven and hell into present day with San Lázaro being judge and jury. To the community, heaven and hell are not places, but ways of living. For the practitioner of Santeria, heaven is an Ire' [Positive Ashe'] state of life while hell would then become Osogbo [Negative Ashe'] state. All practitioners wish to be Ire', but Ire', is an element of this culture, that must be acquires by either ebbo or good deeds. So as thousands of Cubans migrate to the States yearly, they bring with them their Afro-centric habitus and concept of Babaluaiye; this allows us to see how the continual use of African principles to alleviate the suffering of social conditions has given them full confidence in Babaluaiye and his miracles. Therefore, revealing why Babaluaiye’s Ashe’ is the most sought after Ire’ within the Yoruba pantheon. 


\section{CHAPTER III \\ THE BIRTH OF EL SANTO}

During the mid-1700s to the early 1800s, the West African shores and their people were ravaged by the strong hold of colonial imperialism. The industrial revolution as well as the Cuban sugar rush made it necessary for African slaves to be exploited within the plantation systems of the Caribbean. Cuba's fertile soil and untouched lands gave way to one of the largest amount of slave trade efforts of the time. De La Torres explains,

The demand for sugar in the late seventeenth century triggered a demographical revolution in the West Indies as more and more Africans were brought to the Caribbean to work on the emerging sugar plantation. It is conservatively estimated that nine to ten million slaves crossed the Atlantic; of this number 6.3 million slaves are estimated to have been transported from West Africa, and of these, an estimated 23 percent came from the Slave Coast[ western Nigeria, Benin, and Togo] while 42 percent came from the Niger Delta and the Cameroons. For about three quarters of a million to 1.3 million slaves [7 to 10 percent of the total], Cuba was their destination (De La Torre, 2004).

Within the shores of Cuba, a combination of peoples from different African kingdoms disembarked. It was at that time that the Olukumi or Lukumi [which translates to my friend] was spawned. The term Lukumi comes from the variety of groups from the West regions of Africa who recognized each other's similarities, such as dialect and beliefs at the moment of oppression and became cohorts against their persecutors. Amongst these African captives were millions of men, women and children, who today are categorized around the world as the Yoruba people. The Yoruba as mentioned prior is a grouping of peoples from the West African coast that have similar dialects, such as the Oyo, the Dahomey, and the Egbas kingdoms.

When these captives arrived on the island, the Spanish crown imposed its Christian ideology on their belief systems, forcing them into a new structure of belief. Many died in the struggle between one lifestyle and the other. Some preferred taking their own lives to being subdued to a life of slavery and religious reform. For the Lukumi, formal written religion was not 
part of their existence. Religion was not even a learned concept, to the Yoruba; everyday life was not separate from faith. All aspect life are interconnected.

Since the Lukumi were captives and were forced to convert to a new religion, and believe in a new God, this became a shocking concern for them. Many slaves revolted and ended their lives as mentioned prior, some gave in to the Christian ideals and another retained faith in the Orisha via hidden synchronism. For those who retained the devotion of the Orisha, concealing their truth was a matter of life and death. "The historical experience of slavery and repression created an atmosphere of secrecy as the followers of the religion tried to protect themselves from the social forces that threatened them. Under slavery in colonial Cuba, the practice of the religion was technically illegal, and accusations of "witchcraft” could mean imprisonment or death" (Ortiz, 1984). One way that the Lukumi covertly practiced their worship was through the initiative of the Spanish cabildos [lodges] in Cuba.

Much like the ones in Spain, these cabildos were a place for slaves from specific ethnicities to celebrate and exercise traditional customs such as song and dance. "They were started in the 1200s in medieval Spain as religious hermandades [fraternities], serving as guild whose members, belonging to similar occupations, celebrated the feast of the particular Saint that served as patron of the group and provided each other with medical and financial support in times of need” (De La Torre, 2004). However, the agenda of the Spanish was clear; the cabildos were fashioned to gather the captives and try to reform them into Catholic followers. All of the cabildos were run by the Spanish Church. Each cabildo was dedicated to a Catholic Saint and headed by a priest who would overlook the activities of their captive. "Through this guided syncretism, the priest hoped that the Africans would be swept up into the mainstream of Cuban Christianity and in time forsake African customs. In the meantime the church allowed cabildo members to inject an African flavor into the European Christian rites” (Brandon, 1997). Since the 
Lukumi found themselves permitted to worship Catholic Saints, much like all traditional African cultures, the Lukumi gathered what they regarded as useful for their needs and created the foundation for the religious complexity called Santeria.

Thus, it was within the walls of these cabildos that Santeria was born, nurtured and became a solidified force in the lives of the worshippers. The Catholic priests who supervised the cabildos were oblivious to the structures of the tradition imperceptibly taking shape right under their noses. For the Spanish crown and the church, the cabildos furnished a context for reforming the African. Unfortunately for the Spanish, the Lukumi turned the cabildos into spaces for performing their cultures and sustaining their sense of identity. Cabildos were noted for their impressive dance performances. This was a major regular recreational activity of the cabildos. There were African dances performed in the style of the nation after which the cabildos were named. The most important dances occurred on the Catholic religious holidays, but the dances performed remained African in origin and style. As noted by Brandon, "It would be very surprising, indeed, given the intimate relationship which exist between music, dance and religion in African cultures, if these dances did not turn into religious ceremonies at times, complete with spirit possession” (Brandon, 1997). The cabildos gave the Lukumi a space to worship and deities to reconstruct their traditions of their deities. Even though the function of the cabildos was to initially quiet down the slaves all it did was fuel the fire of the Orisha within them. "In truth, these cabildos created a space where the religious traditions of Africa could be preserved and passed down to ensuing generations. Unbeknownst to the Catholic authorities that organized the cabildos, they provided a social structure crucial to the survival of Yoruba religious beliefs and rituals” (De La Torre, 2004).

Hence, Santeria is a combination of African practices along with Catholic influence, it is not singularly African. The Catholic tradition gave the Lukumi supplementary grounds to dwell 
in, versus the removal of something authentic. Santeria and its progression is as authentic an Africa tradition as any. So when the captives of Cuba found themselves confronted with a new ideology, a new God and new ways of worship, they did not erase the supremacy of their old convictions, they simply augmented their spiritual views with a new structured model. Birthing what today we can describe as the Saints/Orisha [Los Santos].

One way that the captives began to restructure and amplify their principles was by the retaining their systems of divination, which I will elaborate on later in the text as well as augmenting the Catholic word Santo into their vocabulary. Santo can be directly translated as Saint, such as is applied to the Roman Catholic faith but has a completely different meaning for the Lukumi. For the Catholics, the idea of Saint is to be a messenger of God on the Earth. However, for the Lukumi, the word Santo also is the messengers of God and includes the AfroCuban Orisha. The Church and The Saints gave the Lukumi, a pantheon for them to hide within. Due to similarities in attributes; Ellegua became EL Nino de Atocha, Obatala became our Lady of Mercy or Las Mercedes; Chango became Santa Barbara, Oshun became Our Lady of Charity or La Caridad de Cobre and Babaluaiye became el Santo Lázaro or San Lázaro.

Nothing could better underscore the difference between the ecclesiastical and folk understanding of Sainthood. For the church, Saints were human beings who led virtuous lives; they manifested in human form the spectacle of realized holiness. The folk, however, did not focus on the inner religiosity of the Saints nor focus on them primarily as exemplary religious figures, models of what human beings should or could be. Instead they sought the external signs of the Saints' ecclesiastical virtues, signs which could be manifested as forms of power and generosity that could made a difference in their own daily lives. For them the Saints were humans who had miraculous powers (Gudeman, 1976).

After years of enslavement, the Lukumi were freed from their binds on October 101886.

“Slavery ended comparatively late in Cuba, being phased out in stages until around 1888”

(Brandon, 1997). Freedom from slavery however, did not mean freedom to practice Orisha worship. It was only through underground gatherings, that concealed worship would take place. 
One thing that was prevalent, those who believed in the Orisha, knew where to go when faced with a crisis. They would go to the practitioners, risking their lives specifically, when it came to health issues that no one could alleviate. With little to no medical resources available to them, it was by way of the medicine men and women, who still practiced the Old Ways of pharmacopeia that people would find cures to their most significant needs. "There were no powerful medicines in those days, and no doctors to be found anywhere. It was the nurses who were half witches who cured people with their homemade remedies. They often cured illnesses the doctors couldn't understand. The secret is to trust the plants and herbs which are the mother of medicine” (Montejo, 1968).

For many years now, it has not been uncommon for Cubans to seek out curanderos and curanderas [medicine men and women]. Even though the tradition and its practice was considered to be illegal until the 1992's. These curanderos, include ritual specialist such as Babalawos, Obas, Babaloshas and Iyaloshas; who conduct rituals of divination to alleviate the dis-eases that occurs mentally, physically and spiritually within the populace. My studies show that in Santeria, if one tries to seek assistance from San Lázaro, generally the individual is obligated to consult with the ritual specialist and their systems of divination. This oracle system has been accepted and utilized among the Santeria community in Cuba and abroad to access detailed information about the person seeking guidance.

The oracular system is based on one used in Nigeria, the Holy land and origin of the Yoruba, the predecessors of the Lukumi. There, before humans knew of Orisha or Odu, there was only Orunmila. Born from Oludomare, he was the great witness to creation, and knew all things. Orunmila incarnated among mortals, bringing infinite knowledge of Odu and divination to earth. What he taught is known as Ifa. The sacred science of Ifa was first passed down to Ashe'da [the first Ifa priest, or Babalawo] and then to Akoda [the second disciple]. Together, these two men spread Orunmila's cult of divination among the Yoruba, and it was from this that the original sixteen-cowrie shell oracle emerged (Meyers, 2000). 
Whether it is Asojuano, Babaluaiye or San Lázaro; the community looks for support through his various representations. As a researcher, I began to stir my inquiries on how this community communicated with and received advice from San Lázaro and his manifestations. It was at that moment, in the study, that I realized, that aside from the Orisha himself, a vital component of this community were the medicine men and their systems of divination. In Santeria much like in its African predecessor, the ones who hold the key to this sacred communication are the Obas [a high ranking priest of the Santeria]. These are the men who are known to be the initiator of the religion and the persons who assist initiated into the mysterious of the Santeria religion. The Babalawos ["Father of all secrets" from the priesthood of Ifa] are the clergy of the Santeria religion and a break of by way of their divinatory utilization of Orunmila [Orisha of divination], without the use of these ritual specialists, communication with this or any entity would be a complicated or an impossible task. A systematic technique used by the Santeria community to receive assistance from San Lázaro or Asojuano is through its two similar, yet distinct divination ceremonies. These ceremonies though comparable by the utilization of the 256 Udos [sacred text], are also distinct by two separate but equal ritual specialist; the Oba's and the Babalawos.

The Obas are the ones who are responsible for the ceremonial aspect of kariosha [initiation to the faith]. The Obas, deploy the diloggun [cowrie shells] as a divination tool to help the initiate in matters concerning their path [camino] in the spiritual, emotion and material world. When the 16 cowrie shells are cast, the reading is determined by how the cowries fall. The 16 cowries have two sides; the open mouth and the closed. The interpretation of the diloggun is then a formulation of 16 X 16, combinations which creates the sum of the 256 . These 256 combinations then become the Odus [sacred text] of the tradition. Once the Odu is revealed, the Oba is able to consult the individual by reciting the sacred text that coincides with the casted Odu 
[sacred text]. Each combination has an Odu that is represented by a parable or Pataki. The sixteen major Odus of the Oba’s diloggun are the following.
1. Okana
9. Osa
2. Eji Oko
10. Ofun
3. Ogunda
11. Ojuani
4. Irosun
12. Ejila Shebora
5. Oche
13. Metanla
6. Obara
14. Merinla
7. Odi
15. Marunla
8. Eyeunle
16. Merindilogun

During a casting, if a combination begins with Metanla, the community recognizes if as a warning from San Lázaro. Wedel, elaborates on these castings in the following,

When the cowrie shells are cast and give more than twelve mouths up, the client is advised to visit a Babalawo for a more profound reading. The person might be suffering from a serious problem, such as a severe illness, particularly when Metanla, thirteen mouths, come up. One of the proverbs for Metanla says, "Where the illness was born,” and the lord of illness, San Lázaro, speaks through the sign. San Lázaro advises the consultant to visit both a Babalawo and a biomedical doctor for a profound medical examination. It is probable that the person has an illness related to the blood or skin, and it is most likely infectious. The illness may also be a venereal disease, and the person is at risk of having an abnormal child. The client is further advised not to have children with kin, not to mistreat dogs [San Lázaro is related to dogs], and not to curse a pregnant woman, because the curse will affect the fetus. The letra [letter] also denotes madness, a fetus that has become the victim of sorcery, and a virgin who has been raped (Wedel, 2004).

The following are a list of Metanla castings directly connected to San Lázaro and are recognized as signs of illness within Orisha worship. *Tonti translates to "in conjunction with”.*

13-1 Metanla Tonti Okana:

13-2 Metanla Tonti Eyioko:
1.Coming of disease and death.

1. Death living behind the ears. 
2. As soon as a man is born, he begins to die.

3. Only a scalpel can insult death.

4. Sickness is the preamble of death.

13-3 Metanla Tonti Ogunda:

13-4 Metanla Tonti Irosun:

13-5 Metanla Tonti Oshe:

13-6 Metanla Tonti Obara:

13-7 Metanla Tonti Odi:

13-8 Metanla Tonti Eyeunle:

13-9 Metanla Tonti Osa:

13-10 Metanla Tonti Ofun:

13-11 Metanla Tonti Ojuani:
1. Death is deaf and she is not frightened by screams.

1. He who closes his eye does not eliminate danger.

2. He who doesn't know their partner might find them at the hospital.

1. Bad blood produces infection. He how lives a lot could die before his time.

1. The king does not tell lies.

2. The truth is born from a legends

1. The skin is the mirror to your health.

1. The Dr. gives the remedy the sickness, the sickness you found yourself.

1. Your worst enemy can be yourself.

1.The sickness that hides will one day come ashore.

2. Be careful when vising the sick, so that you don't end up changing places.

1.We lose health when we believe that we are immune

13-12 Metanla Tonti Ejila Shebora: $\quad$ 1.Failure for being mischievous.

Metanla is an Odu of manipulation and a struggle for authority. It is in this Odu, that persons who suffer unjustly at the hands of another are pardoned by San Lázaro. In this Odu, San Lázaro is considered Olofin’s lawyer. If any of the previous castings are received, practitioners are advised to consult Ifa and the mysterious of Asojuano immediately. Though there are 16 Odus, it is believed by the community, that once a casting of Metanla or above in prophesied, the responsibility of the individual lies on the Ifa clergy. 
In Ifa, much like in Santeria the Babalawos employ the Opele [Ifa divination tool], a chain like instrument made out of eight concave and convex shell pieces. After reciting the initial prayers for divination [moyurba], when the chain is released, the eight pieces can be either read on the concave portion or the convex portion. This gives the Babalawos a combination of 16x16 readings that equal to the 256 Odus that correlate to the Ifa corpus. The Ifa corpus is a collection of poems, myths, chants and other oral genres featuring mostly the exploits of the Orisha. It is the kernel of Yoruba beliefs and practices. It contains answers to all spiritual questions. Asojuano speaks in the Odu of Ojuani [11]. In this Odu, Asojuano warns of disease, droughts, or famine. In Ojuani, Asojuano tells us that "Water cannot be carried in a basket”. Here the prophecy Ojuani speaks of the winds carrying epidemic because the rain refused to fall. This prophecy connects Asojuano to mosquitos, vultures, and all other insects or animals that transport infection. Similar to the Obas, the Babalawos will recite the Odu and consult the individual about their troubles through the use of both allegory and patakis. At times the work of these specialist is to communicate with the client's guardian angel [eleda] or primary Orisha and inquire as to how or what will aid in reestablishing the balance of the afflicted. "An ability to detect illness and energetic disturbances reliably and accurately in a person's etheric body days or weeks prior to the appearance of actual physical symptoms would be truly miraculous”(Richard Gerber, 2000). This communication takes place in a ceremony known as a registro or consulta [consultation]. These ritual specialist and divination systems play a vital role in receiving assistance from San Lázaro or Asojuano.

In Cuba, when a person cannot afford a doctor or has had a concerning medical visit, they turn the ritual specialist for a consulta. A consulta much like the word articulates is a consultation. Though Cuba has always bragged about their free and remarkable health care, what has not been revealed is the amount of healing taking place via the ritual specialist. Due to its secretive nature, it was only through communal assistance that one could visit a ritual specialist 
and partake in the mysterious of the Orisha. This familial reception, gave the individual seeking assistance, a fraternal arena to voice their issues. It was through these specialists and their divination process that the community applies their ancient knowhow to access concerns and summon the assistance of San Lázaro if divined. The following is a descriptive look at a registration or consultation [registro or consulta].

A consulta begins firstly by the priest or priestess reciting a Moyurba or [invocation prayers] to Oludomare, to the Eggun and to the Orisha asking their permission to do the work and asking them to accompany the ritual by speaking about the situations affecting the life of the person coming to be seen. Then the opele or the diloggun [divination tools] will be cast in order to get the essential Odu or specific indicator amongst the 256 Odu that accompanies that person. This Odu [indicator] speaks of the person's life, the road they are on, how they came to be on that road, and where the path leads. First, however it is important to find out the particular path of this sign. Once the Odu has been cast then, the ceremony precedes to determine the state of the person's Ashe'”. This is done to further pinpoint the client's condition. Through these divination tools and ceremony the inquirers will either be found Ire' [healthy] or Osogbo [unhealthy].

Several questions are then asked starting with whether the Odu comes with Iré or with Osogbo. During this time various items called Ibos [supplementary divination tools] will be given to the person is asked to shake and separate the items, one in each hand. The Ibos usually consist of a small bone, a shell, a black rock or a diviners individualized supplementary tools. The results that come up through the casting will direct the client and tell which hand to ask for. This is done so that the client's Ashé or spiritual energy is brought into the equation. It is via this instant that Santeros ascertain what kind of blessing or negativity is accompanying them and where it comes from, etc. At this point the consultants begin to tell the individual what advice Ifa or the Orisha 
has for them. Finally, the ceremonies or effort that is needed to ensure the Iré [blessings] or to defend the individual from Osogbo comes to light.

As mentioned prior, Iré signifies the concept of being “blessed”. Iré like its Jamaican counterpart is something balanced, in alignment with your fate, and peaceful. In Santeria there is only one Iré and it is fleeting and difficult to maintain. On the other hand there are numerous Osogbo which suggests "misfortune”. In the tradition, Osogbo reins the Earth, and Osogbo is everywhere. Osogbo is difficulties, challenges, unbalances, and often violence. It is accepted that each type of Osogbo is seen as an entity, an actual being that brings forth misfortune. The following are some variations of Osogbos: Ikú - death, Arun - sickness, Araye - chaos and arguments, Ona - closed roads and obstacles, Ofo - loss, Ogo - witchcraft, Fitibo - unexpected sudden death, and Egba - Paralysis. These Osogbos can be associated to the countless symptoms that have been assessed and need to be tackled. Once the individual has received the reading, if the divination presents the mark of Osogbo Iku, Arun, Fitibo or Egba at that moment, the high priest will typically recommend what is known to the Santeria community as an Ebbo, [Sacrifice or Offering]. Ebbó is a unique ritual because of the fact that it allows Orisha worshipper to alter their path. It magically seals a pact between the client and the Orisha or Eggun, so that they can lift the Osogbo off of the client and return them to a state of Iré. Once the client completes his obligatory ebbo, they are brought back into a state of Iré. On occasion different models of ebbo are recommended. When San Lázaro is the Orisha that comes to defend the needs of an individual for realignment there are numerous ebbos which one can petition the assistance of San Lázaro.

These ritual specialist, divination systems, and application of Orisha devotion has been the support system of holistic restoration in Cuba for decades. Never was this practice sought after more than in the early 1990's when Cuba experienced its special period. During that time, a resurgence Lukumi practices emerged and San Lázaro regained his role as healer to the 
community. Cuba's AIDS epidemic along with the economic crises, reinforced the devotion of Babaluaiye and San Lázaro as divine healers of contagious and sexually transmitted disease. The following chapter will discuss how through African habitus, the Afro-Cuban population found a support system within a crippling oppression. The chapter will discuss the various situations where Cuban’s looked to San Lázaro and the Orisha for relief.

Between 1953 and 1958 Fidel Castro and his men in arms, battled against Batista to gain control of the island and were victorious. This victory created uncomfortable conditions for some individuals who inhabited the island at the time. Fidel's regime promoted communism and was agnostic towards organized religion. Castro was largely influenced by the ideas of Karl Marx. The Marxist notion that organized religion furnished a conducive context for the elite of societies to exploit the masses was an important ideological basis of the revolution's anti-religion stance. Not only was religion not available to the populace but the Afro-Cuban's role in Cuba was trivial. It was not until Dec 22, 1975, when Fidel Castro made a speech, at the Plaza de la Revolucion in Habana, on the importance of the African culture in Cuba, he announced that, "We are not only a Latin American country, but also an Afro-Latin country... The blood of Africa runs abundant in our veins” (Wedel, 2004).Yet this seems to be mere rhetoric. For Afro-centric rituals were still not publically permitted.

In the 1990s, The AIDS epidemic and the Special Period augured well for the revival of the traditions of the Orishas in Cuba. By 1991, the USSR had collapsed and Cuba's support system had been cut off. The fall of the super power had cast a shadow upon the economics of Cuba and its people. Like a plague, casting a cloud of despair over the island, medical resources, food supply and other vital reserves had reached a frighteningly insufficient amount. This time in history, compelled the citizens of the island to revert to the once ousted traditional African remedies, which are largely religious in nature. When Castro and his associates were confronted 
with what can easily be identified as an epidemic, they agreed that it would be in the best interest of Cuba, to seek remedies from supernatural sources which had been practiced prior but had been shunned. Rumors of Fidel's grouping with Lukumi experts scurried throughout the island.

At that moment the Black Magic Economy was manifested. The Black Magic Economy was a series of experiences on the island, which involve the Orisha which led to the generating of economic sustainability as well as all round well-being at a moment of crises. The Castro government constructed a plan that would reinstate financial stability to the island and revive the Orisha tradition once again. Whether it was his initial goal or not; the new idea of allowing the practice of Santeria in public, was welcomed by many as a move that held much hope for Cuba. By promoting an Africanized world view on the island, Castro generated social restoration.

One way that Castro sought to bring capital into the island was by introducing tourism to Cuba. This was a radical move on his part, as he has been known for his non-consumeristic Marxist ethics. However, with Cuba struggling against an outbreak of hardship, famine and disease, and the population growing weary and rebellious, this was the most convenient strategy to introduce monetary revenue to Cuba. Visitors reached the island from all over the world for vacationing purposes but through the cracks of immigration, countless went to partake in AfroCuban ceremonies; myself included. Ceremonies such as initiation into the Ifa clergy and priesthood into the mysteries of Santeria were organized all over the island. "In post-Soviet Cuba, Santeria became and important economic factor in the country's financial rescue as tourist flocked to the Spanish Antilles to savor Afro-Cuban religious culture and "medicine” (Murrell, 2010). People from all around the world came to cities such as Matanzas, Palmira and La Habana to experience a more traditional system of ritual. For many, going to Cuba as the only way that they could be initiated into the secrets of San Lázaro or Asojuano, as it is expressed by the elders 
of the religion,” That ceremony only exist in Cuba, do not let them lie to you” [En Cuba es adonde vive esa ceremonia, que no te digan mentira].

A second way that Castro instilled the African habitus into the community was by allowing prominent tourist attractions such as Varadero Beach and the city Habana to use the artistic styles of African folklore and Orisha Worship as center pieces for the entertainment. For instance it is not uncommon to see folkloric dance troupes performing traditional Afro-Cuban Orisha shows in the high-end hotels such as the Howard or El Nacional. Paintings, wooden sculptures and Afro-Cuban paraphernalia are also vastly sold through the islands small consignment stores or kiosks.

Lastly, Castro took a look at the pharmacopeia utilized by the religious practitioners, and began research on the various concepts and their results. Practitioners believe that the divine Ashe' of Olodumare lives within the healing properties of the plants. Hence, he took action by allowing physicians to utilize this botanical know how when Cuba's medical supplies began to run out. Murrell states that, “During periods of repression, especially under Castro’s regime, when Afro-Cuban religions were proscribed, herbalist preserved and protected knowledge of the medical plant use that was often done in secret, and as a result prevented this knowledge and the practices of Cuba’s plant-based traditional healing from becoming extinct” (Murrell, 2010). Castro even permitted the selling of these botanical herbs and spices on the city streets, as well as the rural areas, for the health benefits of the citizens. These herbs, for hundreds of years were known to be associated with San Lázaro and have curative properties. Herbs such as Cundeamor, [Momordica Charantia], Caldo Santo, [Cnicus Benedictus] and Albahaca Morada [Osimum Basilicum] were now being sold in corner stores and private homes. Though the profits gained by these acts was minimal, once it was multiplied, it brought in income that fed families, medicine 
for the ill and some revenue for the state. Many people described the turnaround in terms of a miracle that had occurred in a moment of distress. Wedel captures the situation in the following,

The change is partly due to a more relaxed attitude from the Cuban government; partly due to the fact that people see healing as a powerful alternative and complement to biomedicine; and partly because of the economic crises has given belief in Santeria new force, as people use tradition methods to resolve problems related to the crises (Wedel, 2004).

Due to these changes of policy, in the island, Santeros were able to practice again without apprehension. Reliance on the Orisha began to find its way back to the Afro-Cuban community. Medicine was substituted by pharmacopeia; despair was replaced by hope and the emptiness of a state in crises was healed by San Lázaro. What happened next, generated the practices and customs related to the populace’s African roots and their devotion to San Lázaro in the United States.

\section{CHAPTER IV \\ CUBA TO MIAMI: THE PURPLE PASSAGE}

Prior to the 1959 Cuban Revolution, migration to the U.S. had already begun. Due to the political changes, those who opposed fled, creating one of the first substantial migrations from the island. As they reached shore, Babaluaiye reach the US with them. It was in the late 1940s and into the 1950s, that the United States was introduced to Babaluaiye. Babaluaiye unexpectedly became a house hold name. Once again engaging with migrants who acquired assistance in this new world. It was Desi Arnez, a Cuban migrant from the city of Santiago de Cuba, who made himself and Babaluaiye famous by way of the I Love Lucy show. Desi Arnez became the Cuban role model; a migrant Cuban who has made it to the top, utilizing the exotic sounds of Babaluaiye as his crutches. De La Torre offers a few word on the impact of Desi Arnez and Babaluaiye on the American populace.

Throughout the 1950s, the character of Ricky Ricardo in the popular television sitcom, $I$ Love Lucy entertained viewers with his signature song, Babalu-Aye. Desi Arnez, playing 
Ricky, beat his conga drums and strutted around the stage to the amusement of a predominantly Anglo audience. The audience delighted in the Latin beat that came from Ricky's drum, conquering up images of a more exotic culture. But what most television viewers failed to realize was that Ricky Ricardo was singing to Babaluaiye, one of the deities, called Orishas, of an Afro-Cuban religion known as Santeria. They were unaware of what the Latin community recognized: he was engaged in a sophisticated choreography that descended from the African civilization of the Yoruba... (De La Torre, 2004).

After the first wave of immigrants in the 1950s, the Peter Pan Project followed.

Approximate 14,048 children came to Miami, with hopes of a better future (Conde, 1999). These children were all moved to the US, leaving their home and family behind. These children suffered detachment issues and were sent alone to battle in a new land. This kind of isolation and transfer from one country to another, gave these children a patron in San Lázaro. As these same children have grown in the states, the intensity of their devotion has grown with it. In the early 1980's, the Mariel Boatlift took place, bringing another group of up to 125,000 new migrants to the coast of Miami (Triay, 1998). A large percentage of these immigrants were political prisoner that Castro wanted oust from the island. These migrants, miraculously freed and given a second chance of life also incorporated the belief in San Lázaro as well to their lives. Furthermore, during the Special Period from roughly the early 1990’s till 1993, the rafter [balsero] experience grew more than ever, transporting countless undocumented Cubans to American shores. Thousands of migrants, isolated, fearful, and looking for some kind of hope reached deep into their Africanized beliefs and arrived in Miami.

Migrating to the U.S. can be accompanied with a range of emotions. It can also be physically demanding. For the most part, the new arrivals on the shore of the U.S. felt joyous relief that they had escaped the brutal dictatorship of Castro; but the experience also bombarded them with difficulties linked to their status as migrants. Anxieties of displacement which include but are not limited to changes in gender roles, social-economic status, diet, health care and family 
dynamics generate compounded challenges. A sense of solitude in an unfamiliar world becomes as trying as oppression.

Despite the relative success of their adaptation to U.S. society, members of the first generation of exiled Cuban experienced a great deal of stress from a number of sources. The elderly in particular exhibited the harassed double consciousness of the exile. Behind was the past, loss, separation, nostalgia for the old ways, and sometimes death; ahead was the future with its uncertainties, fears, and imagined perils. In the present, though, were all the problems of adjusting to a society of strangers with a different language and customs (Brandon, 1997).

Under those elevated angst, the community had to find a way to so solve these new issues, so again through their "habitus" they found solace in San Lázaro: the healer of woes, the doctor of the sick and the friend to those who walk alone. It has been these constant struggles that have promoted the relationship between San Lázaro and the Cuban migrant community in Miami.

So who is San Lázaro today in Miami? Is he the same African spirit that we inquired about before? No he is not, he can’t be. Presently, the Orisha worshipping community, like its African predecessors have become greatly influenced by the practice of supplementation via necessity. At the moment, it is the trans-cultured San Lázaro who most of the Santeria culture in Miami is venerating. He represents a combination of a stern African ethical teacher and a Catholic miraculous healer. Furthermore, the community still holds San Lázaro in the highest regard, however we can see slight differences in how he is worshipped. Minimal yet thought provoking differences to those who know the history of the spirit.

For Instance, during the 2014 NBA finals this past season, I came across a picture via social media of San Lázaro wearing a Miami Heat Jersey with the caption "We need a miracle" and another one that said, “Only in Hialeah” .To some religious elders this action can be seen as sacrilegious, disrespectful and even dangerous. Yet others view it as their way of asking for a helping hand from a supernatural being reputed for his miracles. These subtle changes reflect on some of the ethos of Cuban migrant life in Miami. Anything is fair game when it comes to 
necessity. For Santeros if there is a need, there is a way. This Saint is so accommodating to the needs of the community that during my research, I found supplications to San Lázaro that span the hardships of man that include: missing children, lost dogs, prayers for the sick and the allaround cry of those who suffer. These pleas were initiated in a variety of manners.

During the course of my investigation, I documented two methods that are commonly advised practices in conjunction with this archetype. The first practice commonly used by the community to receive assistance from San Lázaro is by making a vow [una promesa]. A vow is and intention, contract or promise that one makes to God or the gods. This promise or vow is binding, unlike a pledge made from man to man, a failure to give God or the Saints what had been promised, is a matter of serious offense and has repercussions. For those trying to seek the assistance of San Lázaro, vows can be as simple as wearing yellow and purple for a number of days, while others vows can become a more complex.

During the course of my investigation, I realized that there is specific vow that pertain to San Lázaro. The most predominant way to receive a blessing from this Saint is by honoring his name. Hence, by naming of children Lázaro or Lazara for a variety of reasons, brings the Ashe’ of San Lázaro. The two following interviews give an example of how the community utilized the expression and devotion towards the Saint by way of naming children for solidified well-being

\section{LÁZARO JAVIER CHAVIANO}

I sat down with a young devotee of San Lázaro by the name of Lázaro Javier Chaviano. Lázarito, as he likes to be called, is a 22 year old Cuban immigrant who has been in the US for four years now. His connection to St. Lázaro is to say the least interesting. I first met Lázarito, in Cuba when I went to crown Osha in his neighboring town of Lajas, Cuba. Though at that time we did not become familiarized with one another, three years later, I saw Lázaro in Miami at a bembe 
[drumming] for Oshun at a Hialeah home of worship. During our conversation, we began to catch up and I shared my studies with him. I asked him if he had any information that he would like to share about Babaluaiye or San Lázaro. As we sat and shared some Cuban coffee and a cigarette [common in the culture], he said "I can help you". [Yo te puedo ayudar]. Then with a deep sigh, he looked at me and said, "But this is heavy stuff”. [Pero esto esta fuerte]. So while the drumming was coming to a close, Lázarito began his story.

He said "Well, my name is Lázaro because of a vow that my father made San Lázaro”. [Bueno, mi nombre es Lázaro debido a una promesa que hizo mi padre]. He continued by expressing that when his mother was approximately six months pregnant she showed signs of a premature birth. She was having painful contractions and the doctor told them the baby might be born before its time and might have some issues. This made both his father and mother both fear for the unborn child's life. He continued by saying, “En ese mismo dia mi padre fue al Rincón de San Lázaro en la Habana y hizo una promesa con San Lázaro”. [That exact moment my father went to the Rincón de San Lázaro in Habana and made a vow to San Lázaro]. "He vowed that if I was born healthy, he would name him Lázaro”. [El juró que si hubiera nacido sano, me nombraría Lázaro]. Though the naming of a child does not seem as a vow that carries much foundation, when I became more affiliated with the story it made more sense. Lázarito told me that what was special about the vow was that for over three generations, all the men of his father's side were named Javier, Mario Chaviano, and that because of this promise made by his dad, he is the only one whose name was changed, breaking an almost 100 year tradition. I then asked him "how he felt about it and if he still engaged with San Lázaro”? He said, "Well I’m here, I'm healthy and I didn’t die. And I know that Old Man Lázaro is always with me”. [Bueno yo estoy aqui y estoy saludable, y no me mori. Y yo se que El Viejo Lázaro siempre esta con migo]. 


\section{THE DIAZ FAMILY}

Another account correlated to the naming of a child was Lázaro Diaz from the Diaz family. While speaking to the youngest, Frank, about the reason why his brother as named Lázaro, Frank expressed to me that his brother Lázaro was born on December $17^{\text {th }}$. I asked him, “If he came from a religious family”? He replied, “No, not at all”. “Then why would your brother be named after the Saint”? He replied, "My family is not religious at all and definitely not Santeros. From what I heard, during the times when my brother was being conceived, it was no mystery that my father was a ladies man. When my mother gave birth on December $17^{\text {th }}$, she saw it as a sign. In her heart, she believed that the birth of this child was going to be the miracle that she was expecting with my father. She named my brother Lázaro not only to praise the Saint, but with the hope in her heart that the child would be a solidifying element in their relationship”. With a grin and a laugh, Frank sighed,” Yeah that was like over 50 years ago. Those two are still together. And the funny thing is, that every year for my brother’s birthday, my mother always does something special. Maybe she has been practicing magic all this time, I just thought it was birthday parties, but now that I look at it, I have to wonder”.

During my study, I found that followers of this spirit keep some kind of picture, statue or representation of San Lázaro, such as commemorative note cards that goes in wallets or purses. I also came across people who have tattoos of San Lázaro on their bodies. Others showed me their 8 foot statue of San Lázaro in front of their home. Others make vows such as wearing San Lázaro's colors or sackcloth every year on the $17^{\text {th }}$ of December to commemorate and give praise to him. An abundant and imaginative choice of deeds are performed for his blessing. One thing that recurs is this spirits demand for respect and honor.

One of the vows that was particularly intriguing to me, was that of the mimicking of a shaken and incapacitated San Lázaro. I saw this vow performed by sisters Estella and Estrella 
during my investigation. These sisters both in their mid- 60's were the talk of my December $17^{\text {th }}$ investigation at El Rincón de San Lázaro in Hialeah. When I first saw them, it was quite an exemplification of faith. Estella the older of the two, was on the floor crawling on her belly, shaking and making her way into the church. Her sister Estrella was in front of her, clearing her path with a makeshift broom like instrument made of palm leaves or branched of a tree. Crawling on her belly, Estella was emulating the shaken and incapacitated San Lázaro. People in the crowded building made way for her, as they innately knew that she was fulfilling a vow. The crowd would say, “They come here every year, some sort of promise that they’ve done for years”. [Ellas vienen todos los anos, Una promesa ase muchos anos]. I tried to interview Estella and Estrella but had no luck. These two women were a clear representative of the blending that had occurred throughout the years. It was evident that these women were praising a combination of Fon-Yoruba-Catholic entity, with their $J a$ and their vow.

The other ebbo that I found to be the most concurrent to this study, is the periodical use of Awán [ritual cleansing], as directed by the Saint. This type of ebbo can be marked by the ritual specialist, is a specific cleansing of the aura. The Awán can be marked by any Orisha however its mystery’s is closely related to Babaluaiye. An Awán is a ritual cleansing that allows for an individual to cleanse their aura by way of organic components. Many Santeros employ the Awán when they are about to enter into the mysterious of Babaluaiye as well as when directed by any Orisha. This cleansing is something that as a researcher I encountered constantly. This method of cleansing is a prime example of how animism is conceptualized in the religion. It is through Babaluaiye that this community cleanses itself of the unwanted negative energy or Ashe'. The following is a brief explanation of an Awán.

Perhaps the most common ceremony for worshiping Babaluaiye is the Awán. In the ceremony, a basket is lined with sack cloth with many plates of cut-up food encircling it. Some elders say 13 plates, some say 17 , and some even say 77 plates must be present. After sunset, participants gather round the basket and taking handfuls of food from each 
plate into their closed hands, rub the food around their bodies to remove negativity or osogbo. Each handful of food is cast into the basket, until everyone has cleansed themselves. People are also cleansed with a speckled rooster, a guinea hen, two eggs and the Já, the ritual broom of Babaluaiye. Different lineages finish the Awán in different ways, but these things remain pretty stable wherever you go (Mason, 2002).

\section{MARY}

Most of the people who took part of my research provided feedback about how San Lázaro and his manifestations contributed to their lives, either by a clean bill of health or changes in a physical malady. However, the next account was one that I never thought I would encounter. To protect the identity of this individual, we will identify her as Mary. Mary’s story is one of necessity, prostitution and reformation. During her interview, Mary told me that when she was a young girl in Cuba, around age 20, she had to become a prostitute to basically survive. "I was a prostitute” [Yo era una ginereta]. She shared that both her parents had died when she was in her teens and that after their death she had to fend for herself. So she began to prostitute, "I knew that I was putting myself in a risky situation” [Yo sabía que me estaba poniendo en una situación de riesgo]. She knew that she was in danger of becoming contaminated with a number of diseases was imminent.

Her plan was to save money and leave to the U.S. As time went by, she began to save money and commenced her escape from Cuba. She continued to let me know that she really didn’t believe much in the Orisha at that time, and that she was brought up to basically be spiritual and believe in God but that all. That other stuff wasn’t her cup of tea. “However, because she was about to spend a couple of thousand dollars to take this trip, she figured that there would be no harm in checking out what these people were talking about”. [Pero iba a gastar tanto dinero en el viaje, así que fui, que iba a perder, así me enteré de lo que todo el mundo estaba hablando]. She said that when she first met her now God-father [padrino], she wasn't very impressed. "Some old man”. [Un viejo] However, as soon as he sat her down and began to use the divination 
system and shared her prophecy, she froze and didn’t know what to do. “I froze” [Quedé

paralizada]. Not only did he know about the fact that she was going to leave the island, he also knew that she had been placing herself in danger to leave. He said, "Be careful with blood disorders and sexually transmitted diseases”. [Ten cuidado con las enfermedades de sangre].

During the consult, her godfather told her that the Saint that defended her was Babaluaiye. "What’s wrong with me, am I sick”? [Qué pasa conmigo, estoy enferma]? "No but you have to take care of yourself". [No, pero tienes que cuidarte]. At that point, he began talking to her about her profession as well as the story about San Lázaro and Ochun. It was at that time that she figured out what how it all corresponded to her. "The Legend about San Lázaro and Ochun changed my life”. [El Pataki de San Lázaro con Ochun me cambio la vida]. After the initial consultation had finished, her padrino told her that as long as she wanted to stay healthy, it was imperative for her to respect San Lázaro. He then told her, that it was to her best interest that she cleanse herself with different legumes or herbs attributed to San Lázaro, after her encounters. After every client, she would cleanse with either Cundeamor or black eyed peas and after a few months, she was on her way to the states and free of any STDs. Today, she says that she goes to the church every year on the $17^{\text {th }}$ of December to give thanks to San Lázaro for protecting her and getting her to the states safely. "There is no Saint more miraculous than San Lázaro”. [No hay ningún santo tan milagroso como San Lázaro]. This Awán or ritual cleansing can also be used for assistance from Babaluaiye for success and prosperity. In his book Ritual and Spells of Santeria, Wippler gives us a twist on this practice that give devotees the impression that San Lázaro can accommodate his followers with monetary prosperity.

This is a lengthy ebbo that requires the use of two gourds. One is filled with several types of dried grains and legumes, such as corn, rice, garbanzo beans pigeon peas and black beans. The other gourd is placed on a large blue cloth next to the other container of the mixture. Each day some of the mixture is taken from the gourd using both hands, which are then passed over the entire body. The two fists are kissed and the mixture is then placed in the second gourd. This action is repeated every day until all of the mixture is 
transferred from one gourd to the other. Again the mixture is transferred to the first gourd, and finally, for the third time, it goes into the gourd with the blue cloth underneath. The mixture is then poured onto the cloth and tied in a knot, and the petitioner cleanses himself with it for the last time. The bundle is brought to the woods with seventeen cents in Babalu's name (Wippler, 1984).

The idea of this Saint being miraculous and able to heal and bring prosperity, presented itself regularly while studying this group. Another essential reflection of this spirit is the dreaded wrath that the community feels towards him. The next interview will give a look into the how San Lázaro is affiliated with the act of death itself and why he is sometimes called "he who kills and is thanked for it”. The following is an interview with a woman who believes that San Lázaro took the life of her failing grandfather.

\section{LUCY PEREZ}

While I was doing my research, I encountered Lucy Perez at a drumming for the dead [Cajon de Muerto] that was taking part in Little Habana. Lucy is a woman in her mid-fifties. She came to the states in the 80's in her early 20's and has made a life for herself in Miami. Lucy is not a Santera, Lucy is what the community calls a Muertera [A person who practices ancestral worship [Espiritistmo] and is connected to the community not by faith but by art. Lucy is a restoration expert. She is the person who is commissioned to create religious statues as well as restore them as need be. When I began my interview with Lucy, she asked me to forgive her if she became a bit emotional. I didn’t understand at first as her demeanor was pretty intimidating, but as the dialogue continued, I began to recognize her gentleness.

Lucy shared that as a child in Cuba, her family experienced a tragedy and a miracle at once, which she accredits to San Lázaro. She began by letting me know that she is devoted to this Saint more than any other because of his awesome power to touch people at the most pivotal time in their lives, crisis. She continued to tell me a bit about her family dynamic, how her family was very united, and that the lead role model of the family was her grandfather who was also a 
follower of San Lázaro. Months before leaving Cuba, her grandfather became very ill and was on the verge of death for weeks. This moment turned into an agonizing few months for both the grandfather and the family. She continued by telling me that her grandfather's sickness had become terminal but that death was lingering but not taking place. "He was constantly in pain and wouldn't die. We watched a man who was the center of our universe become a shriveled and frail outer shell”. Because Lucy felt that she was the closest to her grandfather, this moment was most painful. After weeks of going back and forth with her family about what to do with her grandfather, Lucy took matters into her own hand and went to the Rincón of San Lázaro in Habana.

Weeping like she never had before, she asked San Lázaro to take her grandfather already and let him and the family be at peace. She recalls vowing to him that if he would take her grandfather, that she would never let a year go by without her celebrating and commemorating his existence on December $17^{\text {th }}$. She said that the next morning her grandfather had passed away at 7:17 in the AM. "The death of my grandfather was a blessing. It made us all a closer family and for me it gave me renewed faith in San Lázaro that is beyond words”. "I have a deep respect towards that Saint”. [Tengo un profundo respeto hacia ese Santo]. I asked her, "If she currently engages with the spirit in any way”? She replied in broken English, [I’ve restored a few statues of him throughout the years but it's not something to play with].

Much like Lázarito, Frank, Mary and Lucy, there are thousands of believers in the city of Miami and all over the world, who believe that this Saint has in one way or another intervened in their lives. During the course of my investigation, I came across those who have 7 foot, yard shrines in front of their homes because San Lázaro assisted them on refinancing of their mortgage. Others have statues or icons of San Lázaro in their businesses to protect them from thieves. Some have him tattooed on their bodies to make sure they never forget how San Lázaro 
saved them from what one person called “An ugly place” [Un lugar feo]. For the Santeria community, there was no issue to big or small that could not be resolved by San Lázaro.

The next step to the study was to find out, why it was that the Catholic community was so fond of their biblical San Lázaros and how they became coupled with the African miracle worker, to become this hybrid spirit. The following chapter, will give the reader an inside perspective on the role of the two biblical Lázaros. It will also walk the reader through the city of Hialeah from December $15^{\text {th }}$, to December 18th and the encounters that allowed this researcher to express, the community’s faith in San Lázaro as a fusion of divine love.

\section{CHAPTER V}

\section{CATHOLIC EXPRESSIONS AND THE EXPERIENCE OF CHURCH}

When I began my study, my initial idea was to become acquainted with how the Roman Catholic Church observes San Lázaro, as I was already well learned in the Afro-Cuban Babaluaiye. Originally, I had very little knowledge of the Saint in the Catholic context, so I journeyed Miami in search of different churches that praised him. Much to my surprise, after visiting approximately five local churches and speaking to some Catholic devotees, I realized that I had been confused all along about San Lázaro. It was while speaking to Isis Ortiz, an usher from a church in Miami, that I realized how many people have a misconception of this Saint. She exclaimed, "The Bishop of Bethany is the sanctified Lazarus, not the martyr. The martyr is the one with the dogs. He is the man in the parable of Luke; The Roman Catholic church does not recognize the martyr as sanctified”. The more I searched, the clearer it became. I found that the Catholic community was facing a spiritual identity crises. Not only was there a theoretical confusion but they were also suffering a symbolic mix-up. A mix up that has generated today's Lázaranian worship. 
While visiting the local churches, I became friends with Padre Orlando Molina, who resides over the Rincón of San Lázaro in Hialeah, as head pastor. While probing about the church's view about the Saint, I asked for his permission to take pictures and videos within the confines of the church between December $16-17^{\text {th }}$ of 2013 . He kindly agreed to my being there as well as to an interview afterwards. The following is my three day experience through the city of Hialeah from Dec $15^{\text {th }}$ through Dec18th 2013 and some of the occurrences that took place in the community within the context of San Lázaro.

December 15th 2013, the citizens of Miami are getting prepared for San Lázaro. Yellow and purple flowers are on sale on every street corner and the Church was getting ready for its yearly procession dedicated to San Lázaro. As December $16^{\text {th }}$ approached, I too began to prepare myself for what I might be observing. Knowing that the nature of these religious assemblies are filled with the sick and disabled. It is customary to see people in wheelchairs or on crutches be part of the proceedings. The sick, the poor and the afflicted who attend, seek the blessing of health for maladies and ailments. On occasion some perform feats of religious devotion that can be deemed uninviting to the eye. However, what occurred was more than I could ever prepare for.

By December 16th, the streets of Hialeah were filled with yellow and purple flowers on every corner. Throughout the neighborhoods of the city, people were asking each other whether they were going to go to the church or partake in the procession. By mid-afternoon, El Rincón de San Lázaro, had already begun to welcome visitors. Many of them wore purple, yellow and white. Other visitors came walking to the church from nearby and far-flung places. Several brought flowers with them to commemorate this miracle working spirit. December $16^{\text {th }} 2013$ was a Monday, a working day in Miami, so the throng that was in the church made one wonder, whether they worked. One man told me that "he had taken half a day off to be there from early 
and that way, he would miss the evening rush that happens every year”. Across the street from the church there was clearly a heavy police presence. Aside from the police, one thing that caught my attention was the amount of people who came with their dogs. Some dogs were even dressed up in purple capes and sackcloth outfits.

The air inside the church and in its vicinity was filled with the pungent stench of cigar smoke. It was difficult to breathe. Cigar smoke and tobacco are generally offerings that are given to San Lázaro as a show of gratitude in Santeria. Many people were also barefoot. Some shared that they had made a promise years ago in Cuba with San Lázaro and they had to continue to fulfill them here. Walking from far flung places and without shoes are some of the ways devotees express their commitment. I found that elderly devotees were certainly the majority, who came to pay their regards. Impressively enough, this year there was a significant number of young men and women in the crowd.

The $16^{\text {th }}$ of December is referred to as the entering or approaching of the Saint, [la vispora del Santo] in both the tradition of Santeria as well as Catholicism. In many local temples and homes, followers of San Lázaro get together to light up candles and have prayer sessions to bring the energy of the deity's healing into their homes; allowing it to present itself. The question however, is who is being praised? Is it the Bishop, the Martyr or the African Orisha? In her narrative, “The Inaccurate Saint: Devotion to San Lázaro/ Babaluaiye in Cuban Culture in Miami, FL”. Alanna Pugliese a student at University of Miami, clarifies the inconsistencies by stating the following,

Lazarus was one of Jesus's close friends and brother to Mary and Magdalene. Lazarus lived in Bethany and preached the word of Jesus. He fell gravely ill and died despite all efforts. When Jesus heard of his death, he traveled to Bethany and went into his friend's grave. Jesus had resurrected Lazarus after stating the following, "Canonized in the year 72 by the Roman Catholic Church, Saint Lazarus was also known as the Bishop of 4 days of him being buried...Lazarus later on moved to France with his sisters and it was there 
were he became Bishop. At 73 years old, on the $17^{\text {th }}$ of December of the year 72 , Lazarus is beheaded because of his faith (Pugliese, 2010).

The above provides a historical outlook on the Bishop of Bethany and the reasons why the community praises this manifestation on December $17^{\text {th }}$.The following passage will give the reader insight on Lazarus the Martyr as is presented in the book of Luke, in the parable of the rich man and Lazarus. This passage provides the reader a glance into the biblical parable, which connects these manifestations to the poor and the sick and teaches a moral lesson.

19 "There was a rich man who was dressed in purple and fine linen and lived in luxury every day. ${ }^{20}$ At his gate was laid a beggar named Lazarus, covered with sores ${ }^{21}$ and longing to eat what fell from the rich man's table. Even the dogs came and licked his sores. ${ }^{22}$ "The time came when the beggar died and the angels carried him to Abraham's side. The rich man also died and was buried. ${ }^{23}$ In Hades, where he was in torment, he looked up and saw Abraham far away, with Lazarus by his side. ${ }^{24}$ So he called to him, 'Father Abraham, have pity on me and send Lazarus to dip the tip of his finger in water and cool my tongue, because I am in agony in this fire. ${ }^{25}$ "But Abraham replied, 'Son, remember that in your lifetime you received your good things, while Lazarus received bad things, but now he is comforted here and you are in agony. ${ }^{26}$ And besides all this, between us and you a great chasm has been set in place, so that those who want to go from here to you cannot, nor can anyone cross over from there to us. ${ }^{27}$ "He answered, 'Then I beg you, father, send Lazarus to my family, ${ }^{28}$ for I have five brothers. Let him warn them, so that they will not also come to this place of torment. ${ }^{, 29}$ "Abraham replied, They have Moses and the Prophets; let them listen to them., 30 “' 'No, father Abraham,' he said, 'but if someone from the dead goes to them, they will repent.' 31 "He said to him, 'If they do not listen to Moses and the Prophets, they will not be convinced even if someone rises from the dead.”. Luke 16 [19-31] NIV.

It is within the construct of these two stories, that we begin to see how present day

Catholic Lázaranian worshippers became entangled. It is this Lazarus in the parable of Luke, which give us a glimpse at the Lazarus represented with the dogs and who is attributed with the sore and ailing health. So why is it that today, we find statues of Lazarus with a purple bishop robe, a golden halo and two accompanying dogs? Transculturation or is it the communities way of blurring the lines of rigid faith and turning to the efficacy of this devotional hybrid? As my research continued, it was my mission to figure out why people flocked to two very mixed up divinities and how Santeria’s Babaluaiye also got mixed in this mashup. 
Analyzing these stories, it came to me, if the Lazarus from the parable of Luke is represented by a man with sores and bodily injury and speaks about divine karma. Then the Lazarus for the biblical book of John, speaks of resurrection and a new life after being relocated from his origin; it is not hard to grasp how Babaluaiye can be easily conjoined. Babaluaiye story is of him becoming ill because of his karma and through ebbo and good behavior was allowed to create a new life for himself away from his origin. This amalgamation, created years ago under the roofs of the cabildos had only intensified throughout the years. The African habitus of augmentation presented itself again. Allowing both Catholics and Santeros an alley in moments of sickness, migration, isolation, reform, and just about anything else within the sphere of the human experience.

Tuesday, December $17^{\text {th }}$, my journey began at Botanica Aye the local Santeria supply store located on NW $57^{\text {th }}$ Ave in Hialeah. I chose to begin my day there first to pick up some articles for myself as well as to see how the locals were preparing for the day's festivities. As I entered the store, the first thing I saw was a two foot statue of San Lázaro with a purple cape and two accompanying canines. The floor beneath him was strewn with moneys of all kind. Pennies, dollar bills, quarters, even Cuban currencies. Today the statue was surrounded by yellow sun flowers and purple blossoms of all kind. The store itself was full of yellow and purple flowers, candles, as many are purchased on days such as today. I noticed that one of the men buying his supplies was wearing a sack cloth outfit attributed of San Lázaro, representing his protective garment. When the woman at the counter gave him his change, he grabbed it, cleaned his aura starting with his cranial area and almost as if he was swirling the energy, finished at his feet. With one finalized move; he placed the coins at the foot of the statue and said "Father what I ask of you is health, health and more health, with that I'll do the rest”. [Yo lo que Te pido padre es mucha salud, salud y salud con eso yo ago lo demas]. 
After a few minutes at the botanica, I came to realize just how important this day was. What intrigued me during my stay at the botanica was how the members of the community would ask each other, “Hey are you going to go to the Church tonight”? [Oye, vas a ire a la iglesia esta noche]? It was a recurring theme. It seemed more like an amazing party that was going to take place and everybody was invited. Later that day at about 12:00pm, I began to make my way back to the church. I saw crowds of flower vendors all throughout East $4^{\text {th }}$ Ave. It was as if the city was washed in yellow and purple for the day. Finding a space to park, even at 12:00pm was difficult. Once I arrived, the church looked like a small carnival. People had kiosk located at a corner of the church, selling San Lázaro paraphernalia such as tee-shirts and small statues, with the iconic San Lázaro, with the golden crown, the purple robe and the dogs. Camera men from different local television stations were also present to capture today’s occurrences.

As I was walking around talking to people and taking pictures, I saw a familiar face. A young Babalawo named Danny, who is a renowned in the Santeria community as a bata drummer and ritual singer arrived with a group of friends. I recognized a few of them as Lukumi clergy and greeted them accordingly. After our brief hellos, I asked Danny, "What are you doing here”? He replied, “I’m going to perform”. [Voy a tocar]. “What”? I replied in awe. He said, “I’m going to drum for San Lázaro”. [Voy a tocarle a San Lázaro], with a smirk I asked, “San Lázaro or Babaluaiye”? He said, "You know”. [tu sabes]. I then asked him, "Did you get permission from the priest”? He said, “Don’t worry about that, everything is good”. [Si, no te preoccupes que todo esto esta cuadrado]. "Remember that in Ifa, I’m Ogbe-Yono, where Babaluaiye gave the Awán to Olokun [Orisha of the deep sea], this is a cleansing for everybody”. [Recuerdate que en Ifa, yo soy Ogbe-Yono, donde Babaluaiye le dio el Awán a Olokun, Esto es una limipeza para todo el mundo]. “Ok”, I said. Then after a few minutes chatting about the community and what was going on at the church, Danny and his group went away to pick up their drums. As a Santera, I was excited to see what this young man and his group were going to do. Knowing well, that they 
were going to venerate Babaluaiye on the church grounds and ritually cleanse everyone. As a researcher however, I found myself contemplating, the legitimacy of the action.

As they returned, I was surprised to see the group of bata drummers set up inside of the church itself. Within minutes of them setting up their drums, a crowd of people circled them. Many of them wearing Santeria paraphernalia, such as Ides [Bracelets] and Collares [Necklaces] of the Orisha. The drums began to sound inside of the church and as if a current of electricity had stricken the building, people began to honor Babaluaiye. In an instant, I began to understand the intensity of the moment. It was a modernized cabildo celebration. It all tied up. As I looked around, it felt as if the Orisha, the Eggun and Catholic priests of the past, were there with us. Every drum beat, generated vibrations within the room that could be deemed nothing less than hypnotic, unifying and in part cleansing.

The most remarkable part of that event was when a woman approached the bata drums as she would have at a Santeria gathering. She took a dollar out from her purse, did the representation of the cross, then one by one, she approached the three bata drums. She would place her forehead on the drum and kiss the drum with her arms crossed in front of her chest; a traditional Santeria expression of respect to the spirit of the drum and drummers. After she had done so, she went into what seemed to be a push up position and prostrated herself in front of the middle drum, placing the money in a basket that the drummers had prepared for donations. While that was happening someone in the crowd shouted, "Who has the dry wine”? [Quién tiene el vino seco]? At bembes [drummings] and other festivities, dry wine is poured on the floor, then dapped on practitioner's forehead and the back of the neck to protect individuals when this spirit is evoked.

The fact that this event and the elements that encompassed it was being done in the context of a Christian worship, brought home to me the cross fertilization that was occurring right 
before my eyes. Aside from this woman's display of blatant Orisha worship, the drummer's front and center positioning, and the calculated intent of cleansing; I found myself in awe. It was as if everything seemed normal to them. As I watched enthusiastically, the number of people crowded around the bata grew even more with no regard for the Catholic context of the happening. However, in the background, whispers amongst a few disgruntled Catholics were muffled but evident.

In the course of the festivities. I spoke to both Catholics and Santeros. One couple that made a lasting impression was a young Catholic couple who brought boxes upon boxes of flowers. Their names are Maria and Jose, they stood at the front entrance of the church and handed flowers to all those who needed them. When I asked them, "Why are you handing out flowers”? They replied, “It’s a promise” [Es una promesa]. “As long as we have a prosperous life, we vowed to come once a year and give flowers to those who can't afford them”. [Mientras tenemos una vida próspera, juramos venir una vez al año y dar flores a quienes no pueden pagarlas]. This type of humble act towards man; Catholic or Santero, that this couple was taking upon themselves as a vow to San Lázaro, demonstrated and confirmed for me the unconditional support that this Saint and his manifestations has to offer its devotees. It also revealed to me the bigger expression of healing through unification that was taking place. "San Lázaro”, the healer was bringing people together, helping them no longer feel alone or isolated or distinguished by faith, or separated by nation.

After two straight days of researching, on December $18^{\text {th }}$ I woke up relatively relieved that I had gathered as much data as I did. December $18^{\text {th }} 2013$ was a special day for me since it was my 4 year anniversary of kariocha [initiation into Santeria]. As I began my day, I got out of bed, only to realize that I could not put any pressure on my right foot. As I kept trying to walk around my home to try to shake it off, I saw myself limping everywhere. I must admit that as an 
Omorisha, I began to panic. It was as if I knew that doing this kind of research was going to come with a variety of issues. I began to wonder whether what the elders cautioned me about was coming true. Was I going to get sick along this process, as they had cautioned? Was this really a dangerous study? All the same, I kept a positive mind and kept thinking to myself, that San Lázaro loves you for what you're doing and will only bring health for your actions.

When my husband, Julio, an Ifa priest awoke, and saw me limping he asked,” What is wrong with you"? When I explained to him that I couldn't walk and felt like if I had a bruise on my foot or one of the metatarsals was out of place, he grinned and replied, “Oh, so you thought that after all that, the old man wasn't going to become close to you”. [Ah, pensaste que después de todo esto que el viejo no iba a estar cerca de ti]? "Remember that you've been around him for the past couple of days. Plus there were numerous energies around you this week that could have affected you” [Recuerda que has estado cerca de él durante los dos últimos días. Además hubo numerosos diferentes energías a tu alrededor esta semana]. I replied that, “I know” but I could not help but feel as if this had become too real.

Though it sounds a bit bizarre or even superstitious to say something like that, this kind of motif about San Lázaro floats around the community of Santeria worshippers. Since the commencement of my study, I stumbled on countless elders who refused to partake in this specific study. "You should be careful”. They would warn me, often, adding in Spanish "Con esto no se juega", [This is nothing to play with]. I would persistently repeat myself by saying that I was not playing with anything, that I just wanted to tell the story of a great spirit. Additionally, I would make a point of addressing the fact that I had consulted with Obatala and Orunmila prior to selecting the topic. But today, I was faced with my fear. I was walking around my home the whole day with a limp that was unbearable. Having minor background in energy medicine myself and being married to an Ifa priest came in handy that day. I took it upon myself to ask for healing 
from Obatala and San Lázaro himself and made Ebbo. The ritual was less than spectacular, just a handful of grains, flowers and household items along with tremendous intention to heal. Maybe I did pick up a bad vibe at the church, I wondered. Maybe San Lázaro was indeed close to me, bringing the essence of dis-ease to my being. Either way, I was not just going to stand there; limping. I prepared a smaller version of the Awán and began to cleanse my aura, asking for assistance in this time of need. Throughout my cleansing, I made sure to set my intention in a place of gratefulness and security in my work. The next morning, I woke up with no pain, my tarsal was back in its place. Miracle? Psychology? Phenomenology? It all depends on what you choose to open yourself too.

This sign of injury became a relevant source of solidified faith for me. This event nevertheless, became a conflicting aspect of my study. After all the research that I had completed and the warnings from my elders along with the outmost feeling of déjá vu that I experienced at the church, I realized that my personal trust in San Lázaro, and my habitus had gotten the better of me. I was no longer doing research from the outside, I was the research. A Cuban-American Santera who believed that she could be afflicted and miraculously cured by an all loving spirit.

\section{FATHER MOLINA'S INTERVIEW}

My experience at the Rincón of San Lázaro was so remarkable that I made sure to go back to interview Father Orlando Molina, the principle pastor. The following is a portion of the dialogue that he and I had during this interview. After initial greetings, my first question to Father Molina was, who is San Lázaro? His reply warmed me. He said, “San Lázaro is Hope for those who are sick”. [San Lázaro para la gente enferma es Esperansa]. “Sick physically”? I asked, and he replied, "No, sick in general”. [No, enfermos en general]. "He is here for the sick, the cripple, the hungry, for the poor”. [El esta aqui para los enfermos, los inbalalidos, los ambrientos, y para los pobres]. “He’s here for complete all around health”. [Para salud 
completa]. This response made me appreciate the role that San Lázaro’s has in the church. For congregates and devotees of San Lázaro, he is a miraculous being, whose capabilities have no limits. Much like Babaluaiye, this Catholic Saint is an all-encompassing miracle worker. My inquiry continued by me asking him; "What does this Saint represent in the eyes of the church”? He began by reminding me that the Catholic Church is venerating the Bishop of Bethany and not the Lazarus from the parable in the book of Luke. I had heard this prior but wanted to clarify the confusion. At that moment, we discussed the scripture itself. I then asked him, "If like me, he believed that some of the followers of his church are confusing the two". He said, "The community is confusing all three”. [La comunidad está confundiendo los tres]. “Three”? I asked trying to figure out if I had missed something within my biblical research. He said, "Yes three, the one from the parable” [Si, los tres, el de pa parabula]. [Luke 1: 19-31] “The Lazarus from John 11 the Miracle of Jesus”. [El Milagro de Jesus en Juan 11]. “And the African one”. [Y el Africano].

"Why do you believe that this unification has occurred"? "Well many years ago the Roman Catholic Church began to place the Lazarus, the martyr with the dogs on church alters and ever since there has been a great deal of confusion”. [Bueno desde ase muchos anos atras, la iglesia Romana Catolica empeso a poner el Lázaro de la parabola en altares y desde ese entonces hay una gran confusion]. During my study, I found that you can rarely find a San Lazarus statue of the Bishop of Bethany in Miami without the accompanying dogs; which has created a series of perplexity. I then inquired about the reasons that his congregation engaged with this Saint, and if there was a recurring theme. He explained, "That it was usually elder women who came to the church”. He expressed to me that people from all walks of the world come to the church to receive the blessings of this miraculous spirit and not just for health. He did emphasize that he has counseled people who have all types of skin disorders; people who suffer from herpes, warts, boils, albinos, even cancer patients. This reply solidified the notion that the 
community as well as the church, continues to allow this blending of figures, instead of rigidly differentiating them. Saint Lazarus, the Bishop of Bethany, as the Roman Catholic Church recognized him, is a Saint of rebirth as portrayed in the bible, nowhere in scripture do we find him to do with bodily injury or harm. It is the Lazarus in the parable of Luke who is associated with bodily injury and physical signs of pestilence. For people to receive assistance for physical well-being through a prayer from a Catholic priest or a vow to this Catholic Saint, only facilitates the unification and misrepresentation of this spirit. At that point, he said something that caught my attention, he stated, "But with all the new problems that our community faces, many people come to us with problems of foreclosure, drugs, alcoholism and divorce”. [Pero con los nuevo problemas que hay, mucha gente viene por aqui por problemas de foreclosure, de drogas y alcholismo y desuniones de familia]. This statement make me appreciate that San Lázaro, whether Catholic or Lukumi had no boundaries on the amount of support it can offer the community. "Can San Lázaro bring support for material needs as well, because you mentioned foreclosure”, he said “Absolutely, people come here for all kinds of support and hope”. [La gente viene aqui para apoyo y esperansa].

We spoke about migration and displacement and how the Saint has influenced the many cultures that reside within the Miami-Dade territory. He expressed to me that one of the things that he finds amazing is the amount of people who are drawn to this Saint, who had never heard of it prior to coming to the States. The multi-cultural interaction in Miami blends ethnicities to cultivate intercultural relationships. "Many people from South America are visiting the church with their Cuban friends seeking support. Especially those from Venezuela, Panama and Hunduras”. [Mucha gente de sur America vienen aqui con sus amistaded Cubanas en busca de ayuda. Gente especialmente de Venezuela,Panama y Hunduras]. "Migrating to this country is not an easy thing for many, there are a lot of changes”. [Migrar a este paiz no es nada facil para mucha gente, hay muchos cambios]. 
Changes and the physical movement of individuals from one place to another is a theme that is consistently spoken about when we speak of Saint Lázaro. Migrations and the woes of change that migrants have to combat, make people seek succor from all possible positive sources. Since San Lázaro has been historically related to such themes as healthcare, monetary prosperity and displacement, his relevance is growing. During my investigation, I understood that migrants from all over the world were being introduced to this patron Saint by the Cuban community as a supplementation for their need for medicine and social structure.

Migrants who come to Miami, rarely speak English when they arrive to this country. This language barriers creates fears and anxiety about going to seek out medical attention in places where the primary language is English. Many times, these same people work or communicate with the Cuban population in Miami and are drawn to it. Migrants who come from places such South America and the Caribbean mutually have diviners and ethno-botany present in their cultures; allowing their own habitus to blend with the Cuban populace to produce even more followers of the Saint.

I continued my questioning by asking him "his opinion on the vows that the followers of this spirit take part in and if the church recognizes these vows"? "We recognize the vows, vows have always been a part of the church, that's nothing new”. [Nosotros validamos las promesas, las promesas siempre a sido una gran parte de la Iglesias, eso no es nada nuevo]. Historically, vows made to San Lázaro were made by soldiers of war, who had contracted leprosy or other skin disorders during war. Historically, vows go as far back as Aquinas to demonstrate love and devotion to God. Then I continued my questioning by asking him "if he had heard of any testimonials about the miraculous power of San Lázaro”? He replies, many people say that the holy water from this church has healing properties. One example was a woman who suffered from severe headache who said she use to bathe with the water and little by little the headache 
began to diminish”. [Mucha gente dicen que la agua bendita de esta iglesia a ajudado curar muchas cosas. Ejemplo, una senora que se echaba la agua bendita en su cabesa por que le dolia y poquito a poco se le empeso a curar].

Then my last three questions generated a long trajectory of discussion. I asked, “On December $17^{\text {th }}$, myself and hundreds of other devotees were witness to a Santeria Bata drumming that took place within the walls of the church entrance; what motivated you to allow that to happen”? He said, “I didn’t give them permission to play inside of the church, I gave them permission to express their devotion as they wished”. [Bueno, yo no le di permiso a esos muchacos a tocar adentro de la iglesia, yo le di permiso a demonstrar su devocion como querian]. "But once they began to drum why didn’t you stop them”? He said, “If that is how the people want to demonstrate their devotion, then that's fine with me “. [Bueno si asi es como la gente quiere demonstrar so devocion entonces esta bien]. We discussed the fact that I had overheard a few people who disagreed heavily with this act and then he replied by telling me a story about a man from Mexico, who was a devote of the Saint, who years back brought a mariachi band to play Las Mañanitas, [A popular Mexican folk song] to express his gratefulness to San Lázaro. Father Molina went on to say that "Many Cubans who were at that event became enraged because of Cuba's alliance with Mexico, and what the man had done was regarded as act against the Cuban exile”.

"Do you believe that aside from this church which is in a predominantly Santeria community would that ever occur”? He replied, “This community here, is very different than in other places”. [La communidad aqui es muy differente que en otros lugares] "The Afro-Cuban influence predominates our city”. [La influencia Afro-Cubana es predominante en nuestra ciudad]. And lastly, I asked Father Molina, "Do you believe God has a role in the unification of these two very different communities and if by way of San Lázaro they are unified versus 
segregated”? "Maybe, the love of God for his children is absolute and can create miracles”. [Puede ser, el amor de dios es unico y puede crear milagros].

\section{CHAPTER VI}

\section{REFLECTIONS AND CONCLUSIONS}

During the course of my investigation, I learned that San Lázaro and his manifestations have influenced the Cuban American Santeria community in Miami because of the historical effect that they have had on the culture. From his origin in Africa, to today’s hybrid Lázaranian worship, it is his dichotic methods of encouragement and determent that distinguish this Orisha from the rest and makes him one of the most sought after spirits in the Yoruba pantheon. We find this historic dichotomy beginning with his mysterious upbringing. Having been born to a goddess who is accompanied by death, Nana Buruku; but being nurtured by the goddess of life, Yemaya, has permitted him access to both side of existence. Within his manifestation in Benin's Oba-luAye tribe, his opposing position as innovative healer as well as skilled technician in the art of warfare, has brought about the fear and respect that the community has had for him for centuries. Again it is his contrasting features that make him an all-encompassing powerhouse amongst the Orisha.

Through my investigations I found that harsh conditions do not sway this spirit, if anything severe conditions makes San Lázaro and his presence stronger. Whether displaced by slavery or oppressed by communism, this spirit gives its followers a sense of alliance in times of desperate need. Followers of this spirit and his manifestations never feel alone. He is the archetype of the wounded healer and as such, he has arrived to cure the injured and relieve the suffering; even if it means taking the life of a failing man.

My studies confirm that San Lázaro’s authority as a supernatural physician has caused thousands of believer to praise his name around the world. Specifically in Cuba and in Miami, 
where Lukumi principles linger, it is not uncommon to find a Lázaro or Lázara in the crowd. So impressive is his reputation within the community, that during my investigation, I did not find one person who denied San Lázaro’s influence. His many names as well as his multifaceted paths allow San’s Lázaro devotees to partake in endless rituals related to health and all around wellbeing that are associated with the attributes of his historical experiences.

In Miami, he is the spirit of reinforcement for those who are overwhelmed by the social difficulties that accompany migration. So evolving is this African spirit, that today he has camouflaged himself again within the Catholic Church. This time however, he is not hiding his true nature but enabling his followers to praise him in unification. We find this blending of characters in today’s San Lázaro paraphernalia. Currently it is a difficult task to find a picture or statue of San Lázaro that does not have the attributed hounds of the Afro-Cuban Babaluaiye or the supportive crutches of Lazarus from the parable of Luke.

In conclusion, this enlightened spirit holds great authority and influence in the Cuban American Santeria community because he permits his followers to regain what they have lost in the past as well attain what they seek in the future. The current rendition of Santeria and Lazaranian worship is now more developed, evolved, and confident, a "Social Cultural Evolution” is taking place. Emile Durkheim states that Social-Cultural Evolution can be defined as the "Process by which structural reorganization is affected through time, eventually producing a form or structure which is qualitatively different from the ancestral form”. Durkheim states that the key to forming society is through social interaction.

As high volumes of immigrants have entered the U.S and other parts of the world from Cuba in the past 6 decades, many Afro-Cuban Santeria religious practitioners have journeyed with them. With freedom of religious practice and the new found use of social media as a passage for teachings, the West is now experiencing spiritual contagion. A contagion that can be regarded 
as Accessible Santeria. Now practiced without chains or social political limits, these Afro-Cuban practices can now reached a new diaspora; into the new world of the 21st century.

With that said I would like to reveal some data collected through this study. In the 2010 Miami Census it shows that $64.6 \%$ of inhabitants in the city are persons of Hispanic or Latino origin $\backslash$ American Indian or Native America make up $0.3 \%$ which give a total of $64.9 \%$. Both these communities come from a population of religious Habitus that have encountered the idea of a curanderos [medicine man or woman] as well as healing deities, Saints, spirits, prayers, botanicals...etc. Add to that the numerous amount of Haitians and Jamaicans the number rises to over $65 \%$ in total. Hence $65 \%$ of the population in Miami have the knowledge of type of holistic health option.

My research shows, that via this archetype lies the potential for greater education regarding Santeria and its benefits amongst the multiethnic population in Miami. Because approximately 65\% of Miami embraces some kind of indigenous practice, we find that they too apply and worship similar archetypes. Essentially my focus would include educating those in the fields of the Law, Health Care and most importantly Learning Facilities. It is my goal as a scholar to generate workshops and lectures on this Afro-Cuban Religion and its systematic divination technique to show how accessing, altering and aligning the Ashe’ of the H.E.F (Human Energy Field) can become an applicable method of preventative health care. This will allow the citizens of Miami to participate in a custom that has been an invaluable resource for Santeria practitioners for centuries to help prevent and even alleviate the afflictions of today's new social tensions. 


\section{LIST OF REFERENCES}

Barkan, Elliot R., Ed. Immigration, Incorporation and Transnationalism. New Brunswick: Transaction Publishers, 2007 1-257 Print

Bourdieu, Pierre. In Other Words: Essays towards a Reflective Society. Stanford: Stanford University Press, 1990. 12-13. Print.

Bourdieu, Pierre. The Logic of Practice. Stanford: Stanford University Press, 1980. 52-65. Print.

Bourdieu, Pierre. In other Words. Stanford: Stanford University Press, 1990. 3-168. Print.

Bourdieu, Pierre. Outline of a Theory of Practice. Cambridge: Cambridge University Press, 1977. Print.

Brandon, George. Santeria from Africa to the New World. Bloomington: Indiana University Press, 1997. 1-157. Print.

Canizares, Raul. Babalu-Aye: Santeria and the Lord of Pestilence. Plainview: Original Publication Spiritual Books and Supplies, 2000. 1-40. Print.

Conde, Yvonne M. Operation Pedro Pan: The Untold Exodus of 14,048 Cuban Children. New York: Routledge, 1999. 1-242 Print

Cortez, Julio G. The Osha: Secrets of the Yoruba-Lukumi-Santeria Religion in the United States and the Americas. Brooklyn: Athelia Henrietta Press, Inc. 2000. 27-472 Print

De La Torre, Miguel A. Santeria: The Beliefs and Rituals of a Growing Religion in America. Cambridge: Wm. B. Eerdmans Publishing Co., 2004. 1-224. Print.

Durkheim, Emile. The Elementary Forms of Religious Life. New York: Oxford University Press, 2001. 3-289. Print.

Erickson, Pamela I. Ethno-medicine. Long Grove: Waveland Press, Inc., 2008. 1-107. Print.

Frazer, Sir James George. The Golden Bough: Taboo and the Perils of the Soul: New York: The Macmillian Company, 1935. Print

Geertz, Clifford. The interpretation of Culture: Selected Essays. New York: Basic Books, 1973. Print.

Gudeman, Stephen. Relationships, residence, and the individual. Minneapolis: University of Minnesota Press, 1976. Print

Herskovits, Melville. The Myth of Negro Past. Boston: Beacon Press, 1969. 1-342. Print

Hillier, Jean, and Emma Rooksby, eds. Habitus; A Sense of Place. 2nd Ed. Burlington: Ashgate Publishing Company, 2005. 3-406. Print. 
Holy Bible: New International Version. (2011) Grand Rapids, Michigan: Zondervan.

Jung, Carl G. Man and His Symbols. Broadway: Ferguson Publishing, 1968. 18-304. Print.

Kearney, Richard. Ana theism; Returning to God after God. New York: Columbia University Press, 2010. 3-182. Print.

Larisey, Katheryn C. "The Wounded Healer; A Jungian Perspective." www.jungatlanta.com. Jung Society of Atlanta, Sept. 2012. Web. 8 July 2014. http://www.jungatlanta.com/articles/fall12wounded-healer.pdf.

Mason, Michael A. Living Santeria: Rituals and Experiences in an Afro-Cuban Religion. Washington and London: Smithsonian Institution Press, 2002. 1-121. Print.

Mason, Michael (2013, Nov 23) Baba who? Baba Lu. Retrieved from http://www.baba-whobabalu-santeria.blogspot.com.>

Meyers, Stuart B. Diloggun Tales of the Natural World. Rochester: Destiny Books, 2011. 1-205. Print

Montejo, Esteban. The Autobiography of a Runaway Slave, Ed. By Miguel Barnet. New York: Pantheon Books, 1968.

Murrell, Nathaniel S. Afro-Caribbean Religions: An Introduction to Their Historical, Cultural, and Sacred Traditions. Philadelphia: Temple University Press, 2010. 13-202. Print.

Olupona, Jacob K. City of 201 Gods. Los Angeles: University of California Press, 2011. 1-282. Print.

Otero, Solimar. Afro-Cuban Diasporas in the Atlantic World. Rochester: University of Rochester Press, 2010. 1-241. Print.

Ortiz, Fernando. Los Negros Esclavos. La Habana: Editorial de Ciensas Sociales, [1916] 1984.

Pals, Daniel L. Eight Theories of Religion. 2nd Ed. New York: Oxford University Press, 2006. 18-292. Print.

Pugliese, Alanna. "The Inaccurate Saint: Devotion to San Lázaro/Babalu'Aye in Cuban Culture in Miami, Florida." http://library.miami.edu/chc/scholars/alannapugliese/. University of Miami, 3 Sept. 2010. University of Miami Library. Web. 31 Jan. 2014. Path: Santeria; Miami; San Lázaro; Babaluaiye.

Ramos, Miguel. Afro-Cuban Orisha Worship: In Santeria Aesthetis in Contemporary Latin American Art. Ed. By Arturo Lindsay. Washington, D.C.: Smithsonian Institution Press, 1996.

Sandoval, Mercedes C. La Religion Afrocubana Madrid: Playor, S.A., 1975. 3-287. Print

Triay, Victor A. Fleeting Castro. Gainesville: University Press of Florida, 1998. 1-104. Print 
Wedel, Johan. Santeria Healing. Gainesville: University Press of Florida, 2004. 1-190. Print.

Wippler, Migene G. Power of the Orisha: Santeria \& The Worship of Saints. Old Bethpage, Original Publications, 1992. 51-59. Print

Wippler, Migene G. Rituals and Spells of Santeria. Old Bethpage, Original Publications, 1984. 7132. Print 
Ahijado/Ahijada/ Omode: Godchild of a Santeria priest or priestess.

Aiye: The Physical World.

Aleyos: Uninitiated followers of Santeria/Lukumi.

Angel De La Guarda / ocha kua kua leri: Guardian Angel.

Animism: From the word anima (soul) the idea of all things having a soul.

Apertbi Ayafra: spouse of a Babalawo and the guardian of the secrets of Ifa.

Araye: Gossip.

Arun, Aro: Sickness.

Asojuno: Representation of divinity as seen by the Ifa Clergy.

Ashe: Divine Energy.

Awan/ Aguan: Translates directly to box. A spiritual cleansing ritual related to San Lázaro (Baba-lu-Aiye).

Babalochas: Male Santero who has initiated others.

Baba-Lu-Aiye: The Orisha of Health; god of skin ailments, illness and infectious diseases.

Balcero: Rafter.

Bata: Sacred Drum.

Bembe: Drumming for the Orisha

Botanicas: Santeria specialty shops.

Cabildos: Societies and meeting lodges for free slaves in Cuba during the $19^{\text {th }}$ century.

Caminos: Paths, personalities or Archetypes.

Collares: Beaded necklaces with colors that correspond to a particular divinity.

Consulta: Consultation/ A casting of prophecy through the use of divination.

Diallogun: Divination system that uses 16 cowrie shells.

Ebbo: Offering or Sacrifice.

Egba: Paralysis. 
Eggun: Spirits, Ancestors or the dead.

Eleda’: Guardian Angel or reigning Orisha.

El Periodo Especial: The Economic Crises that took place in Cuba after the U.S.S.R. collapsed.

El Viejo Lázaro: Old Man Lázaro, used to represent the Lázaro on crutches accompanied by dogs.

Espiritismo: Spiritism. Religious traditions that focuses on communication with spirits.

Fitibo: Unexpected Death.

Ibos: Supplementary divination Tools.

Ides: Beaded Santeria bracelets.

Ifa: Santeria Clergy. Divination system of the Babalawos.

Iku: Death personified.

Ire': Positive or Good.

Iyalochas: Female Santera who has initiated others.

JA: A broom like instrument made of palm leaves. A cane.

Las 7 potencias Africanas: The 7 African Potencies. The 7 Orishas that are most revered. Ellegua, Obatala, Chango, Yemaya, Ochun, Oggun and Orunmila.

Lukumi/ Lucumi/ Olukumi: Directly translated to "Friend or I see you” People of Yoruba descent; Ritual Language.

Muertera: An individual who practices ancestral worship by way of Spiritism or Palo Monte.

Moyurba: An invocation Prayer

Nana-Buruku: Fon Orisha that represents the underground waterways. Suggested Mother of Babaluaiye.

Oba: King.

Oba-lu-Aiye: King of the Earth.

Obatala': The Orisha of peace, purity and justice.

Ochun/ Oxun/ Oshun: The Orisha of love, treasures, who is associated with the rivers and fresh water.

Oduns: Sacred Text consisting of 256 Prophecies. 
Ofo: Loss.

Oggun- Warrior Orisha known as the inventor of all metal works.

Ogo: Witchcraft.

Olofi/ Olofin: The aspect of Supreme creator that assist man on Earth.

Olosi: Devil.

Oludomare: Supreme God and creator.

Olorun: The aspect of the Creator that is represented by the Sun.

Omolu: The Candomble' representation of this divinity.

Omorisha: Child of Orisha (Saint). An initiate of Regla de Osha.

Ona: Closed Roads or Obstacles.

Opele: Divination chain used by Babalawos.

Orí: Destiny.

Oriates: High Priest of Santeria. Ones who initiate or crown others.

Orisha/Orisa/Orixa: African divinities.

Orunmila: Orisha of divination.

Osogbo: Negative or Bad.

Padrino: God Father.

Patakis: Myths and legends about the Orisha and Eggun related to the divination systems.

Promesa: A vow, contract or promise, which one makes to or with the Saint.

Regla de Osha: Another way of defining Santeria.

Sakpata: The Fon manifestation of this divinity.

San Lázaro: An Afro-Cuban Divinity generated by the synchronism of African Santeria and Catholic structure.

Santeria: The merging of Afro-centric world views and the Catholic faith.

Santeros: Individuals who was been initiated into the mysterious of the Santeria Religion.

Shopona Alapado: The one who kills and is thanked for it. 
Yemaya: The Orisha of the Ocean.

Yoruba: A categorical name given to the people of the West Coast African Region. 